Article

\title{
Assessment of Seasonal Energy Efficiency Strategies of a Double Skin Façade in a Monsoon Climate Region
}

\author{
Taehoon Hong *, Jimin Kim, Juyoung Lee, Choongwan Koo and Hyo Seon Park \\ Department of Architectural Engineering, Yonsei University, Seoul 120-749, Korea; \\ E-Mails: cookie6249@yonsei.ac.kr (J.K.); kevinlee2080@yonsei.ac.kr (J.L.); \\ cwkoo@yonsei.ac.kr (C.K.); hspark@yonsei.ac.kr (H.S.P.) \\ * Author to whom correspondence should be addressed; E-Mail: hong7@yonsei.ac.kr; \\ Tel.: +82-2-2123-5788; Fax: +82-2-2248-0382.
}

Received: 14 June 2013; in revised form: 24 July 2013 / Accepted: 7 August 2013 /

Published: 23 August 2013

\begin{abstract}
As climate change and global warming have become two of the most significant environmental issues today, the double-skin façade (DSF) is getting considerable attention as an energy-efficient passive design. This study is aimed at assessing the seasonal energy efficiency strategies of a DSF targeting library facilities in the climate region with hot summers and cold winters. Toward this end, this study was conducted in four steps: (i) establishment of seasonal energy-efficient strategies; (ii) application of seasonal energy-efficient strategies; (iii) analysis of energy saving effect by season; and (iv) life cycle cost and life cycle $\mathrm{CO}_{2}$ analyses for selecting an optimal DSF. Results show that a shaft box DSF energy model $\left(E_{S}\right) \# 2$, which applied winter strategies, was optimal with an energy saving rate of $4.13 \%$, while a multi-story DSF energy model $\left(E_{M}\right) \# 5$, which applied summer strategies, was optimal with an energy saving rate of $12.67 \%$. In terms of savings to investment ratio $\left(\mathrm{SIR}_{40}\right)$ and breakeven point $\left(\mathrm{BEP}_{40}\right)$, the multi-story DSF (3.20; 9 years) was superior. The results of this study can be used for (i) seasonal energy efficiency strategies of a DSF in East Asian monsoon climates, and (ii) as a guideline for the application of a DSF both in existing and new buildings.
\end{abstract}

Keywords: double skin façade (DSF); airflow operating method; thermal insulation; green wall; energy-saving effect; life cycle cost; life cycle $\mathrm{CO}_{2}$; East Asian monsoon climate; library facility 


\section{Introduction}

The recent increase in global energy consumption has led to a phenomenon called global warming and related climate problems, resulting in a growing interest in developing various technologies that aim to reduce energy consumption, including passive designs, which can reduce the energy load of a building [1,2]. Though unrelated to various efforts in reducing energy consumption, the ratio of glazing in building façades has also increased for aesthetic purposes. As a result, direct solar radiation inside the building rose, causing thermal issues as well as increased heating and cooling energy consumption. Particularly, in hot climate regions, the energy cost attributed to the increase in cooling energy consumption significantly increased [3-6]. To solve these issues, various energy saving techniques have been introduced to block direct solar radiation, such as tinted glass, colored glass and phase changing materials. In particular, there is a growing interest in the double skin façade (DSF), which can be implemented in buildings with a high glazing ratio $[7,8]$.

A DSF consists of the external and inner skins, as well as the cavity existing between the two skins. Since the heat transfer on DSF occurs due to the temperature differences among the external skin, cavity, and the inner skin of a building, managing the heat in the cavity in the summer and in the winter is a key issue. Thus, research on: (i) the shading and the airflow operating methods in the cavity and (ii) the thermal insulation of the glass and the inner skin in the cavity have been conducted. Research on thermal management in the cavity of DSF can be categorized into two types: (i) heating and cooling energy reduction by implementing airflow operating methods; and (ii) thermal bridge effect reduction by improving thermal insulation.

First, several studies have focused on the airflow operating methods by opening and shutting the openings in the cavity of DSF. In winter, the heat in the cavity can considerably reduce the heating load of a building in terms of thermal comfort. Particularly, in winter, conducting the heat in the cavity to the building's interior can be maximized by using a static air buffer as an airflow operating method, which seals the heat in the cavity [9-12]. The Telus Headquarters building in Toronto and the Occidental Chemical buildings in Niagara Falls and in New York use a static air buffer as an airflow operating method to reduce heating energy consumption in winter [13]. Additionally, Xu et al. [14] analyzed that $20 \%$ to $30 \%$ of heating energy consumption can be reduced by using a static air buffer in applying DSF to buildings in Japan. Gracia et al. [15] also showed that the static air buffer could save up to $26 \%$ of heating energy consumption in winter. Next, the cooling load on a building can increase in the summer because of the heated air in the cavity [16-18]. Accordingly, in terms of thermal comfort, management of heated air in the cavity in summer is an important issue. Various studies have been conducted on the airflow operating methods in implemented during summertime. It has been shown that the external air curtain as an airflow operating method that opens the openings in the cavity (i.e., allowing the heat in the cavity to travel freely outside) would save cooling energy consumption during summer because the heated air in the cavity due to solar radiation could be removed in advance before being transmitted to a building [9,12-14]. To discharge the heated air in the cavity and the building to outside the building, natural ventilation, as well as the external air curtain, are also considered important [7,18-21]. Gratia et al. [21] mentioned the significance of natural ventilation after sunset in addition to the duration of sunshine through solar radiation in summer. By emitting the heat inside the building through natural ventilation, $25.5 \%$ of cooling energy consumption was saved [7]. 
Based on the previous studies related to the airflow operating methods, there was little research that simultaneously applies the airflow operating methods and natural ventilation with the consideration of the climate differences between summer and winter. Therefore, this study focused on the facilities located in the regions with the hot summer and cold winter, simultaneously. The East Asian monsoon climate is divided into a hot and wet summer monsoon and a cold and dry winter monsoon, resulting from the monsoonal flow that carries moist air from the Indian Ocean and Pacific Ocean to East Asia. It is driven by the temperature differences between the Asian continent and the Pacific Ocean. Although the East Asian monsoon climate region (e.g., Seoul) has four seasons including spring and fall, spring and fall only last for a short period in this climate region [22-25], therefore, this study only focused on the climatic characteristics in summer and winter.

Second, as a method of controlling heat in the cavity of DSF, various studies have focused on reducing the thermal bridge effect by improving the thermal insulation of the inner skin. It has been shown that the method was effective in both summer and winter. In terms of the thermal bridge effect, Manz [26] and Perez-Grande et al. [27] conducted studies on reducing heating and cooling loads by improving the thermal insulation of the inner skin glazing. Other studies have also shown that improvement in the thermal insulation of the inner wall reduces the thermal bridge effect [16,28-31]. Feist [30] has shown that heating and cooling energy consumption increases due to the unnecessary heat transfer caused by the thermal bridge effect on the wall in addition to the window. Evola et al. [31] determined that there is about $3.5 \%$ of the increase in cooling energy consumption due to the thermal bridge effect of the building skin during summer.

Other studies have focused on reducing the thermal bridge effect by implementing a green wall (GW) on a single skin façade (SSF) [32-36]. Studies showed that installing a GW on the facades of a two-story building could reduce the cooling load on a clear summer day by $28 \%$ [33]. Akbari et al. [34] has shown that the installation of a GW would reduce heat transfer by $0.24 \mathrm{kWh} / \mathrm{m}^{2}$. Likewise, other researchers have shown that the use of plants as shading devices in warm or tropical regions would reduce the cooling load in summer as they helped create a sun-blocking effect [35-38]. These previous studies on thermal bridge effect have concentrated mainly on SSF buildings, while only a few considered DSF buildings. Therefore, this study focused on reducing the thermal bridge effect by implementing GW as the seasonal energy efficiency strategies of a DSF.

In conclusion, it has been shown that in implementing DSF, the management of heat in the cavity is a very important control factor in cooling and heating energy consumption reduction. Therefore, this study aimed to establish seasonal energy efficiency strategies, and evaluate the effect of these strategies to efficiently manage heat in the cavity of DSF. Furthermore, it aimed to implement these seasonal energy efficiency strategies to four types of DSF, and select an optimal DSF after conducting life cycle cost (LCC) and life cycle $\mathrm{CO}_{2}\left(\mathrm{LCCO}_{2}\right)$ analyses.

This study was conducted in four steps: (i) establishment of seasonal energy efficiency strategies; (ii) application of seasonal energy efficiency strategies; (iii) analysis of energy saving effect by season by applying seasonal energy efficiency strategies; and (iv) $\mathrm{LCC}$ and $\mathrm{LCCO}_{2}$ analyses for selecting an optimal DSF. The scope of this study included library facilities located in Seoul, South Korea, which is part of the East Asian monsoon climate region. As mentioned spring and fall only last for a short period in this climate region, therefore, this study only considered winter and summer characteristics to establish seasonal energy efficiency strategies (Figure 1). 
Figure 1. Research framework.

\section{Assessment of the Seasonal Energy Efficiency Strategies of a DSF}

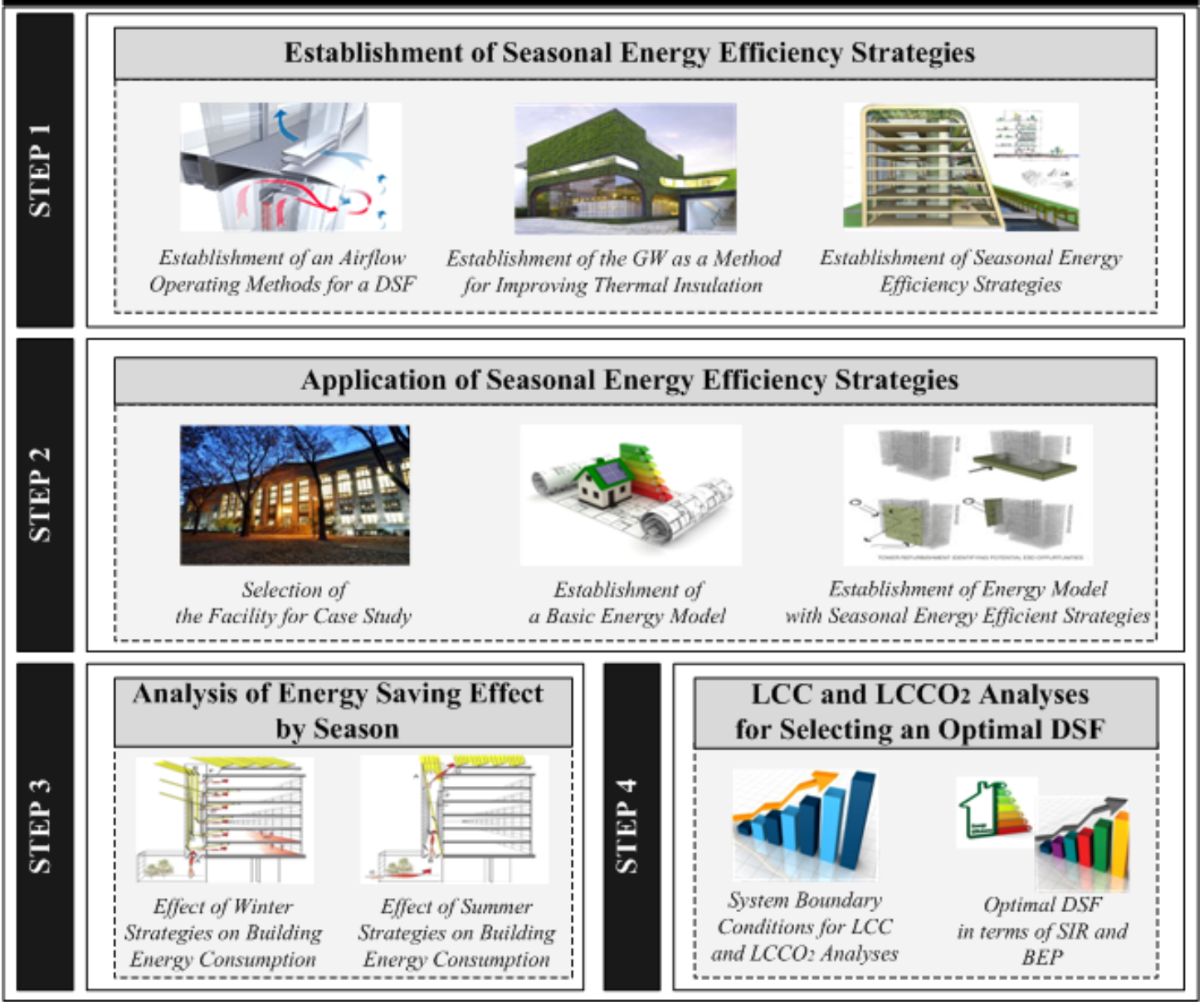

\section{Establishment of Seasonal Energy Efficiency Strategies}

As mentioned above, this study aimed to establish energy efficiency strategies focus on hot summers and cold winters. Under these seasonal characteristics, the airflow operating methods should be selectively implemented according to hot summers and cold winters. To establish seasonal energy efficiency strategies, this study considered the following methods: (i) a static air buffer as an airflow operating method to improve the effect of DSF in winter; (ii) an external air curtain as an airflow operating method to improve the effect of DSF in the summer; (iii) natural ventilation as an airflow operating method to improve the additional effect of DSF in summer; and (iv) GW as a method for improving thermal insulation to improve the effect of DSF in both summer and winter. Based on these methods, this study established seasonal energy efficiency strategies in summer and in winter.

\subsection{Establishment of an Airflow Operating Method for a DSF}

To establish the seasonal energy efficiency strategies of a DSF that can reduce the heating and cooling energy consumption, airflow operating methods that consider the climatic environment should be established. DSF can be categorized by the airflow operating methods and shapes. A review of over 60 historical cases of DSFs installed globally shows that the airflow operating methods and shapes of 
DSF are variable depending on installation purposes and climatic environments [12,39]. These historical cases presented the operating strategies of a DSF according to the seasonal characteristics rather than those in specific region or climate.

The airflow operating methods of DSF depend on the airflow types of DSF. Meanwhile, the airflow types are variable depending on the types of openings installed in the cavity. As shown in Figure 2, airflow type can be divided into a total of six types, based on the opening and closing of the openings: (i) external air curtain (\#1, \#2); (ii) internal air curtain (\#3, \#4); (iii) supply air (\#5, \#6); (iv) exhaust air (\#7, \#8); (v) full open (\#9); and (vi) static air buffer (\#10).

Figure 2. Airflow types of double skin façade.

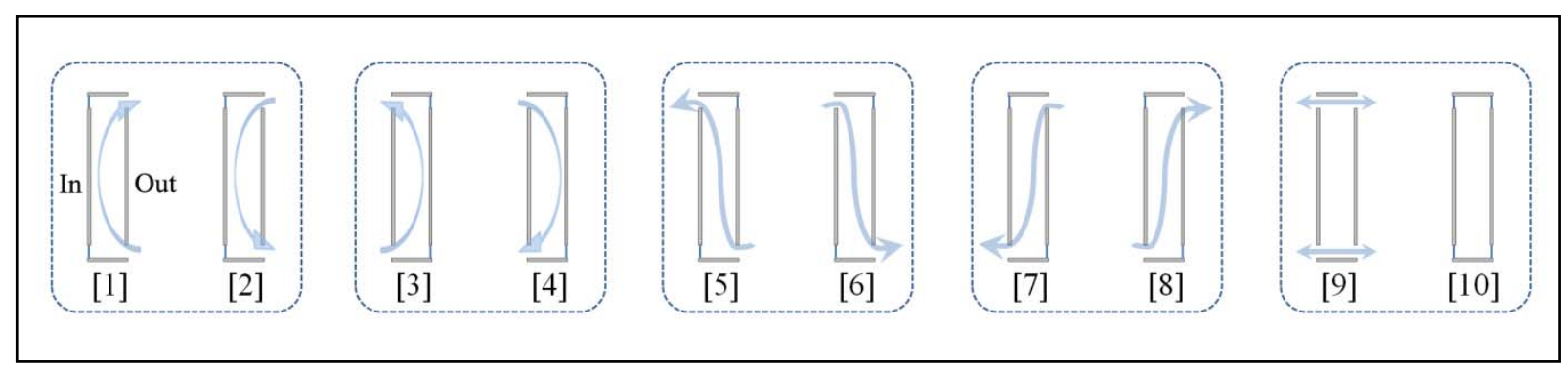

In the East Asian monsoon climates with clear seasonal characteristics, the airflow operating methods should be implemented selectively according to season. In winter, it would be advantageous in terms of thermal comfort to close the openings since external temperature is always lower than inside the building. Existing studies and cases have shown that, as mentioned in the introduction, the static air buffer is the optimal type in winter because it acts as a thermal buffer [9-15,38] (Figure 3a).

Figure 3. Seasonal airflow operating method of a DSF: (a) Static air buffer as winter airflow operating method; (b) External air curtain as summer airflow operating method; (c) Natural ventilation as summer airflow operating method.

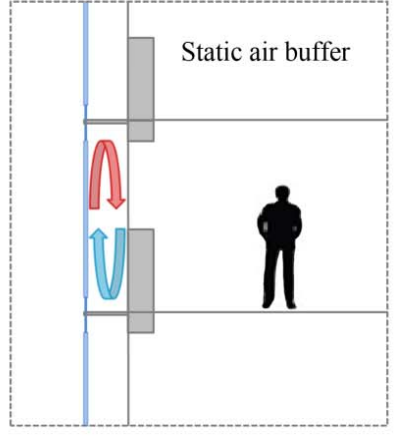

(a)

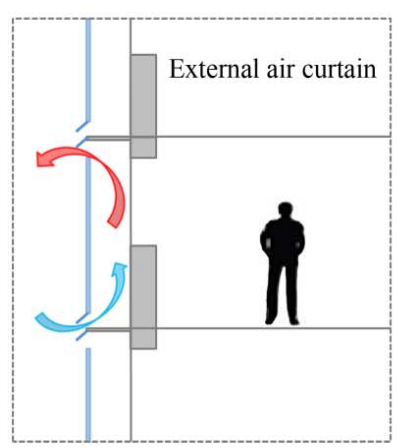

(b)

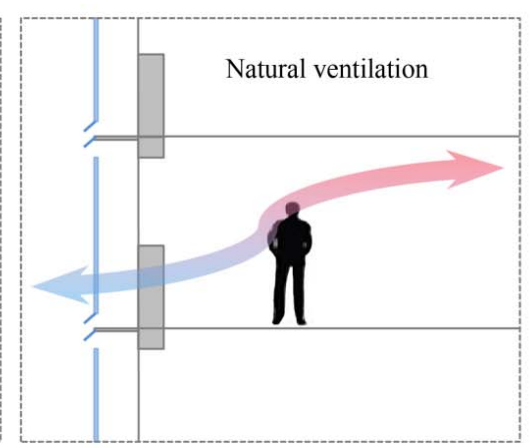

(c)

In summer, an airflow operating method should be used appropriately since the relationship among the temperature outside the cavity, inside the cavity, and inside the building changes over time. Within the duration of sunshine, in which the external temperature is higher than inside the building, closing the openings inside the building would be advantageous in terms of thermal comfort since the heat gained by solar radiation would be removed in the cavity before it enters the building. Therefore, as mentioned in the introduction, the external air curtain is the optimal type because it can extract heat 
gained by solar radiation [40-42] (Figure 3b). Meanwhile, after sunset, when external temperature becomes lower than inside the building, natural ventilation, in which the openings of the cavity are opened, can emit heat inside the building. Therefore, to save cooling energy consumption, natural ventilation can be used according to specific circumstances [18-20] (Figure 3c).

Therefore, this study used the seasonal airflow operating methods of a DSF in the following situations: (i) the static air buffer is used in winter; (ii) the external air curtain is used in summer; and (iii) supplementally, natural ventilation is used strategically in summer.

Meanwhile, the shape of DSF can be generally divided into four types based on the cavity unit of the space that is divided vertically and horizontally [4,43] (Figure 4): (i) the box type with the cavity unit in each room that is divided vertically and horizontally; (ii) the corridor type with the cavity unit in each floor that is divided horizontally; (iii) the multistory type with a cavity unit on the side of the façade; and (iv) the shaft box type adding the box type to solar chimney.

Figure 4. The shape and airflow of DSF: (a) Box type; (b) Corridor type; (c) Multistory type; (d) Shaft box type.

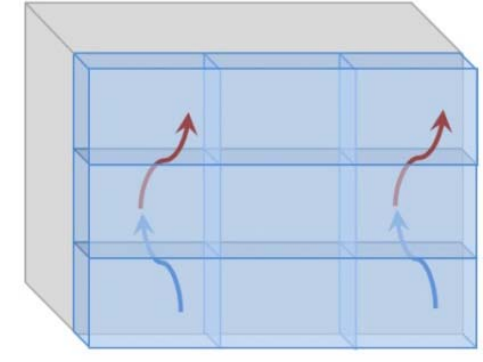

(a)

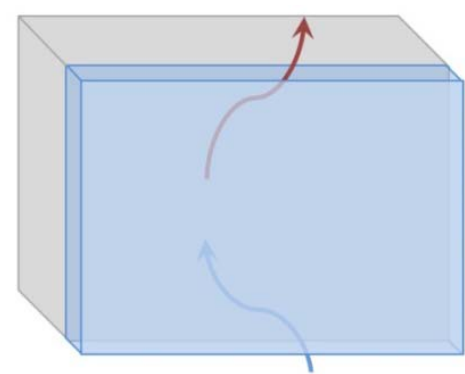

(c)

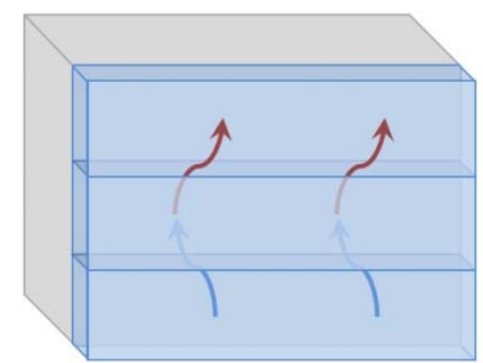

(b)

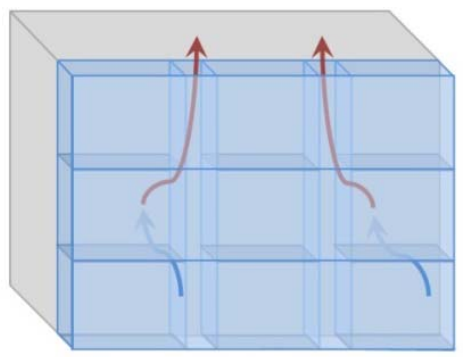

(d)

The box type and the shaft type, which have a cavity unit in each room, have been used mostly for sound insulation. The multistory type, which has a cavity unit in the façade, has been used widely to save construction cost since it requires relatively smaller materials and would be advantageous in terms of natural lighting (Table 1). However, the heating and cooling energy saving effects of these four types of DSF are variable depending on seasonal characteristics and there is no clear priority on which type is optimal to use [44]. Therefore, this study conducted a comparative analysis of these four types of DSF in terms of energy-saving effects by implementing the aforementioned airflow operating methods by season. 
Table 1. Characteristics of the four types of DSF.

\begin{tabular}{ccccc}
\hline DSF type & Box & Corridor & Multistory & Shaft box \\
\hline Vertical division & $\mathrm{O}$ & $\mathrm{X}$ & $\mathrm{X}$ & $\mathrm{O}$ \\
Horizontal division & $\mathrm{O}$ & $\mathrm{O}$ & $\mathrm{X}$ & $\mathrm{O}$ \\
Sound insulation & Good & Satisfactory & Satisfactory & Good \\
Used material & Many & Medium & Less & Very many \\
Natural lighting & Good & Very good & Very good & Satisfactory \\
\hline
\end{tabular}

Note: DSF stands for the double skin façade.

\subsection{Establishment of the $G W$ as a Method for Improving Thermal Insulation}

To establish the seasonal energy efficiency strategies of a DSF that can reduce the heating and cooling energy consumption, this study aimed to select the optimal GW as a method to improve thermal insulation. GWs use mainly three soil types (natural, improved, and artificial soil) and two plant types (sedum and grass). Each type of soil and plant has different characteristics. Therefore, the following criteria were used to select the GW that can offer the highest efficiency in thermal insulation.

First, soil has different characteristics, including thermal insulation, according to type [45,46]. The thickness of soil differs by plant type, which causes differences in thermal insulation $[47,48]$. Also, the lower the unit load, the easier the soil can be attached to the wall. Therefore, the type of soil was selected by considering thermal insulation and constructability. The thermal insulation of soil is highest in artificial soil, followed by improved and natural soil, while the unit load is in the opposite order [49]. As a result, this study selected artificial soil.

Second, the density of foliage and leaf area index (LAI) differs according to the type of plant. The higher the LAI of the plant, the higher its sunblock properties, resulting in further reduction of the thermal bridge effect [50]. The LAI of grass is 2.5, which is higher than that of sedum (2), thus, offering superior sunblock effect. Furthermore, the thickness of grass soil is $0.15 \mathrm{~m}$, which is thicker than that of sedum $(0.1 \mathrm{~m})$, which offers higher thermal insulation. Based on artificial soil, the construction cost of grass is $\$ 106.43$, which is lower than that of sedum at $\$ 133.03$ [51,52]. Therefore, this study used artificial soil and grass (refer to Table 2). The selected GW plant, Kamtschaticum, has spread throughout East Asia such as China, Japan, Sakhalin, Kuril, and Amour as well as South Korea. The climate conditions of these regions are similar to those of South Korea [49].

Table 2. Properties of selected green wall.

\begin{tabular}{cccc}
\hline Soil (artificial) & \multicolumn{2}{c}{ Plant (grass) } \\
\hline \multirow{2}{*}{ Conductivity of dry soil $(\mathrm{W} / \mathrm{m} \cdot \mathrm{K})$} & \multirow{2}{*}{0.2} & Height of plants $(\mathrm{m})$ & 0.15 \\
\cline { 3 - 4 } Specific heat of dry soil $(\mathrm{J} / \mathrm{kg} \cdot \mathrm{K})$ & \multirow{2}{*}{800} & Thickness of soil $(\mathrm{m})$ & 0.15 \\
\cline { 3 - 4 } & \multirow{2}{*}{ Density of dry soil $\left(\mathrm{kg} / \mathrm{m}^{3}\right)$} & Leaf area index (dimensionless) & 2.5 \\
\cline { 3 - 4 } & \multirow{2}{*}{300} & $\mathrm{CO}_{2}$ absorption $\left(\mathrm{kgCO}_{2} / \mathrm{m}^{2} / \mathrm{year}\right)$ & 0.11 \\
\hline
\end{tabular}




\subsection{Establishment of Seasonal Energy Efficiency Strategies}

In Sections 2.1 and 2.2, this study selected four applicable methods to establish seasonal energy efficiency strategies. Then, after dividing them into summer and winter, this study established seasonal energy efficiency strategies. First, the following two methods were combined to establish season energy efficiency strategies for winter: (i) static air buffer (Method_A1) as an airflow operating method; and (ii) GW (Method_B) for improving thermal insulation. Next, to establish energy efficiency strategies in summer, the following three methods were combined: (i) external air curtain (Method_A2) as an airflow operating method; (ii) natural ventilation (Method_A3) as an airflow operating method; and (iii) GW (Method_B) as a method to improve thermal insulation (refer to Table 3).

Table 3. Seasonal energy efficiency strategies.

\begin{tabular}{ccccc}
\hline \multirow{2}{*}{\begin{tabular}{c} 
Seasonal energy $\begin{array}{c}\text { Airflow operating method } \\
\text { efficiency } \\
\text { strategies }\end{array}$ \\
\cline { 2 - 5 }
\end{tabular}} & $\begin{array}{c}\text { Winter } \\
\text { (Method_A1) } \\
\text { Static air buffer }\end{array}$ & $\begin{array}{c}\text { (Method_A2) } \\
\text { External air curtain }\end{array}$ & $\begin{array}{c}\text { Method for improving } \\
\text { Natural ventilation } \\
\text { thermal insulation }\end{array}$ & $\begin{array}{c}\text { (Method_A3) } \\
\text { Green wall }\end{array}$ \\
\cline { 2 - 5 } Winter strategies & $\mathrm{O}$ & - & - & - \\
\cline { 2 - 5 } & $\mathrm{O}$ & - & - & $\mathrm{O}$ \\
\hline \multirow{2}{*}{$\begin{array}{c}\text { Summer } \\
\text { strategies }\end{array}$} & - & $\mathrm{O}$ & $\mathrm{O}$ & - \\
\cline { 2 - 5 } & - & $\mathrm{O}$ & $\mathrm{O}$ & - \\
\hline
\end{tabular}

\section{Application of Seasonal Energy Efficiency Strategies}

\subsection{Selection of the Facility for Case Study}

To analyze the applicability of the seasonal energy efficiency strategies for a DSF, it is necessary to select a target facility. To acquire the feasibility of the analysis, the following criteria for selecting a target facility were established:

- The East Asian monsoon climate region with clear summer and winter characteristics was selected as a target region to determine the energy-saving effect of the seasonal energy efficiency strategies for a DSF;

- DSF results in the heat transfer from the temperature difference among the external skin, cavity, and the inner skin of a building. Therefore, this study aimed to determine the performance of DSF itself by analyzing a building whose energy usage pattern is evenly distributed day and night;

- The type of target facility that is statistically significant in terms of energy consumption was selected, resulting in a great effect on the whole energy consumption of South Korea.

Based on the criteria above, this study selected the Y University library facility, which is located in Seoul, South Korea, the East Asian monsoon climate region with clear summer and winter seasons, as the target building. It also has long operational hours. As shown in Table A1, the space configuration of the library facility consists of reading rooms, study rooms, and PC seats. Especially, the study rooms and PC seats open 24 hours all the year round. Furthermore, air-conditioning and heating system are 
automatically operated 24 hours a day. It was determined that the energy consumption of the university facilities in 2010 was 295 thousand TOE, which is ranked second among all types of buildings in South Korea [53] (refer to Table A2). Especially, the library facility is the main factor of energy consumption and exists in all the university [54]. Furthermore, the most of the university library opens $24 \mathrm{~h}$ a day such as "Y" university library.

\subsection{Establishment of a Basic Energy Model}

To analyze the effect of the DSF on the target building, a basic energy model that reflects the current energy consumption pattern should be established. Toward this end, this study used a building energy simulation software program called, DesignBuilder which was developed in the UK. DesignBuilder is a fully featured version of EnergyPlus, which was developed by U.S. Department of Energy. It was developed to be available at any stage of the design process.

First released in 2005, DesignBuilder allows a wide range of building types to be simulated using the latest version of EnergyPlus. Using advanced design options such as natural ventilation, daylight control, DSF, chilled beams, and heated floors, it can evaluate its impact on the building environmental performance, comfort, cost, and daylight availability [55]. It calculates the heating and cooling loads using the ASHRAE-approved 'heat balance' method implemented in EnergyPlus. There are some previous research which analyzes the DSF through EnergyPlus or DesignBuilder [3,56-62]. Building-related characteristics, as well as user-related characteristics, should be considered in conducting building energy simulation [63]. First, building-related characteristics refer to factors related to the energy efficiency of the building, such as the type and size of the building, the material and standard of detailed components, and heating and cooling system. The front entrance of the target building is facing east, and some parts of the first floor are in a Pilotis structure. To reflect such characteristics, architectural drawings and specifications of the target library facility were used.

Second, user-related characteristics refer to factors related to the energy efficiency of the building, such as occupancy profile and electronic appliance usage schedules. The average occupancy was 1000 per floor based on the survey of a daily average number of people entering the facility and the number of seats. Data on lighting, computers, and office appliances were based on architectural drawings and a field survey. To reflect these characteristics, this study collected the yearly heating and cooling energy consumption data from the manager in charge of machinery room in the target building (Table 4).

To verify the feasibility of the building energy simulation results, tolerance limits for energy simulation offered by the American Society of Heating, Refrigerating and Air-conditioning Engineers (i.e., the coefficient of variation of the root mean square error (CV(RMSE)) were used [Equation (1)] in the monthly difference between actual energy consumption and the simulation-based energy consumption. 
Table 4. Simulation model information of the basic energy model.

\begin{tabular}{ccc}
\hline \multicolumn{1}{c}{ Classification } & Detailed descriptions \\
\hline & Weather data & Climate data in Seoul, Korea \\
& Run period & January 2012-December 2012 \\
& Schedule & Office and library schedule \\
& Conditioning system & GHP (gas-engine driven heat pump) \\
General information & Heating period & January-May, November-December \\
& Cooling period & March-September \\
& Shading device & High reflective roller blind \\
& Total floor area & 6 stories, $16,409.17 \mathrm{~m}^{2}$ \\
& Applicable area for DSF & $645.536 \mathrm{~m}^{2}$ \\
& Applicable area for GW & $385.256 \mathrm{~m}^{2}$ \\
\hline Cooling load & Occupancy & $0.3\left(\right.$ people $\left./ \mathrm{m}^{2}\right)$ \\
& Lighting & $4001 \mathrm{ux}$ \\
& Office equipment & $10\left(\mathrm{~W} / \mathrm{m}^{2}\right)$ \\
\hline Global thermal characteristics & Ground floor & $332.7(\mathrm{~mm}) / 0.250\left(\mathrm{~W} / \mathrm{m}^{2} \mathrm{~K}\right)$ \\
of each wall & External floor & $178.2(\mathrm{~mm}) / 0.250\left(\mathrm{~W} / \mathrm{m}^{2} \mathrm{~K}\right)$ \\
(thickness/conductivity) & Floor & $100(\mathrm{~mm}) / 4.730\left(\mathrm{~W} / \mathrm{m}^{2} \mathrm{~K}\right)$ \\
& Roof & $367.5(\mathrm{~mm}) / 0.250\left(\mathrm{~W} / \mathrm{m}^{2} \mathrm{~K}\right)$ \\
& Ceiling & $100(\mathrm{~mm}) / 4.730\left(\mathrm{~W} / \mathrm{m}^{2} \mathrm{~K}\right)$ \\
& External wall & $292.5(\mathrm{~mm}) / 0.350\left(\mathrm{~W} / \mathrm{m}^{2} \mathrm{~K}\right)$ \\
& Internal partition & $150(\mathrm{~mm}) / 1.923\left(\mathrm{~W} / \mathrm{m}^{2} \mathrm{~K}\right)$ \\
& External glazing & $25(\mathrm{~mm}) / 2.708\left(\mathrm{~W} / \mathrm{m}^{2} \mathrm{~K}\right)$ \\
& Internal glazing & $25(\mathrm{~mm}) / 2.708\left(\mathrm{~W} / \mathrm{m}^{2} \mathrm{~K}\right)$ \\
\hline
\end{tabular}

Figure 5. (CV)RMSE: (a) Gas consumption ("Y" university library); (b) Electricity consumption ("Y" university library).

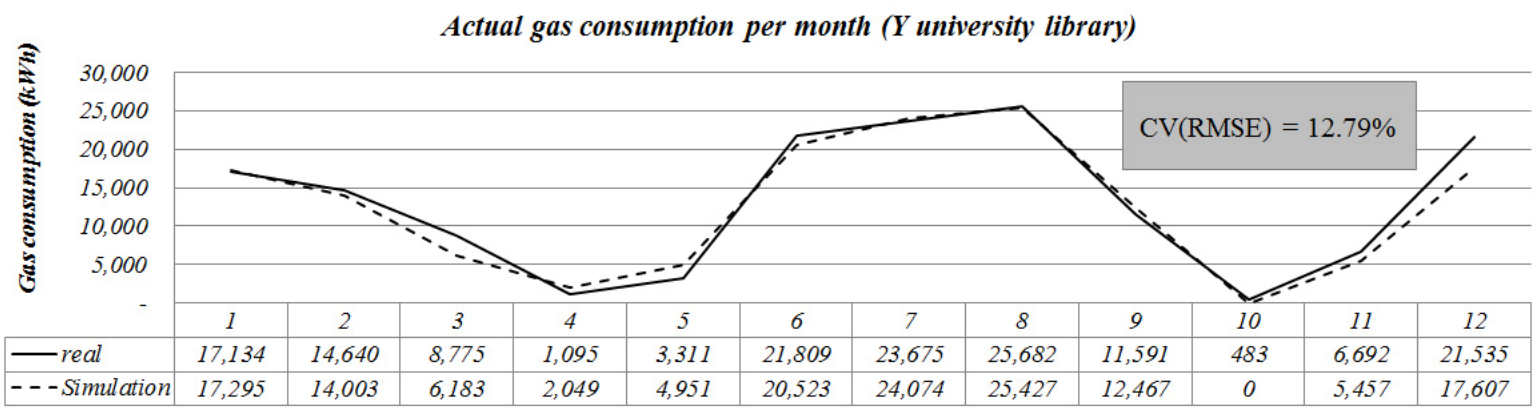

(a)

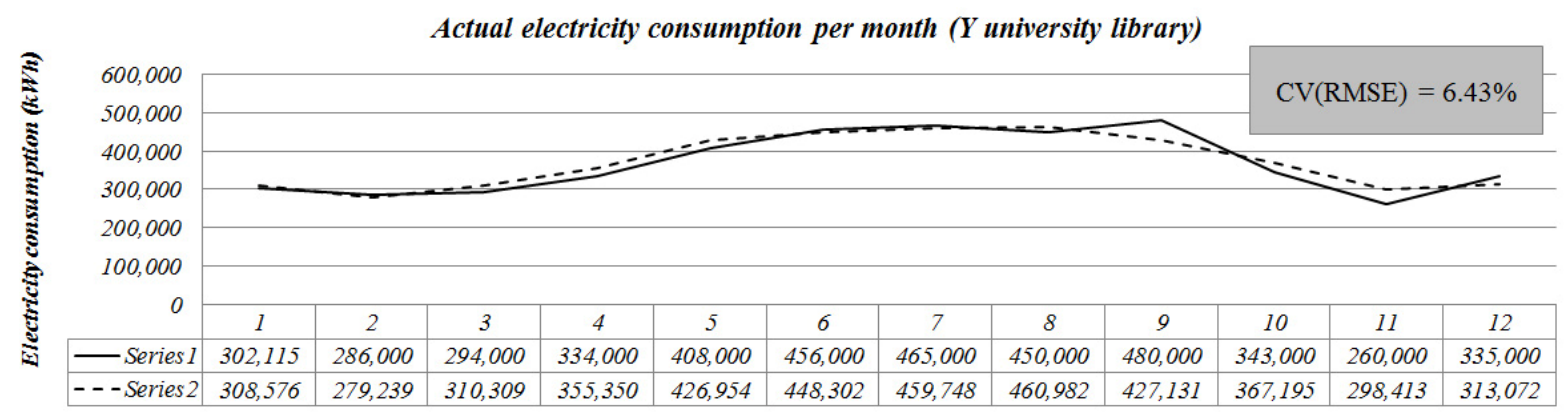

(b) 
The CV (RMSE) values were 12.79\% (gas energy consumption) and 6.43\% (electricity energy consumption) within the tolerance limits (25\%) [45] (Figure 5). Thus, it was determined that the basic energy model was feasible:

$$
C V(R M S E)=\frac{\sqrt{\sum_{i=1}^{n}\left(A E C_{i}-S E C_{i}\right)^{2} \times \frac{1}{n}}}{\sum_{i=1}^{n} A E C_{i} \times \frac{1}{n}} \times 100
$$

where $A E C$ is the actual energy consumption; $S E C$ is the simulation-based energy consumption; and $n$ is the number of data (months).

\subsection{Establishment of Energy Models with Seasonal Energy Efficiency Strategies}

In Chapter 2, this study established seasonal energy efficiency strategies in summer and in winter to improve the effect of DSF implementation (refer to Table 3). Based on these strategies, this study established energy models with seasonal energy efficiency strategies by DSF types, as shown in Table 5.

Table 5. Establishment of energy models with seasonal energy efficiency strategies.

\begin{tabular}{|c|c|c|c|c|c|c|}
\hline \multirow{4}{*}{ Classification } & \multirow{4}{*}{ Energy model } & \multirow{4}{*}{$\begin{array}{c}\text { Seasonal energy } \\
\text { efficiency } \\
\text { strategies }\end{array}$} & \multicolumn{3}{|c|}{ Airflow operating method } & \multirow{4}{*}{$\begin{array}{c}\text { Method to improve } \\
\text { thermal insulation } \\
\text { All seasons } \\
\text { (Method_B) } \\
\text { Green wall }\end{array}$} \\
\hline & & & \multirow{3}{*}{$\begin{array}{c}\text { Winter } \\
\text { (Method_A1) } \\
\text { Static air buffer }\end{array}$} & \multicolumn{2}{|c|}{ Summer } & \\
\hline & & & & (Method_A2) & (Method_A3) & \\
\hline & & & & External air curtain & Natural ventilation & \\
\hline Existing facility & BEM & - & - & - & - & - \\
\hline \multirow{5}{*}{ Box type DSF } & $\mathrm{EM}_{\mathrm{B}} \# 1$ & \multirow{2}{*}{ Winter strategies } & $\mathrm{O}$ & - & - & - \\
\hline & $\mathrm{EM}_{\mathrm{B}} \# 2$ & & $\mathrm{O}$ & - & - & $\mathrm{O}$ \\
\hline & $\mathrm{EM}_{\mathrm{B}} \# 3$ & \multirow{3}{*}{ Summer strategies } & - & $\mathrm{O}$ & - & - \\
\hline & $\mathrm{EM}_{\mathrm{B}} \# 4$ & & - & $\mathrm{O}$ & $\mathrm{O}$ & - \\
\hline & $\mathrm{EM}_{\mathrm{B}} \# 5$ & & - & $\mathrm{O}$ & $\mathrm{O}$ & $\mathrm{O}$ \\
\hline \multirow{5}{*}{ Corridor type DSF } & $\mathrm{EM}_{\mathrm{C}} \# 1$ & \multirow{2}{*}{ Winter strategies } & $\mathrm{O}$ & - & - & - \\
\hline & $\mathrm{EM}_{\mathrm{C}} \# 2$ & & $\mathrm{O}$ & - & - & $\mathrm{O}$ \\
\hline & $\mathrm{EM}_{\mathrm{C}} \# 3$ & \multirow{3}{*}{ Summer strategies } & - & $\mathrm{O}$ & - & - \\
\hline & $\mathrm{EM}_{\mathrm{C}} \# 4$ & & - & $\mathrm{O}$ & $\mathrm{O}$ & - \\
\hline & $\mathrm{EM}_{\mathrm{C}} \# 5$ & & - & $\mathrm{O}$ & $\mathrm{O}$ & $\mathrm{O}$ \\
\hline \multirow{5}{*}{ Multistory type DSF } & $\mathrm{EM}_{\mathrm{M}} \# 1$ & \multirow{2}{*}{ Winter strategies } & $\mathrm{O}$ & - & - & - \\
\hline & $\mathrm{EM}_{\mathrm{M}} \# 2$ & & $\mathrm{O}$ & - & - & $\mathrm{O}$ \\
\hline & $\mathrm{EM}_{\mathrm{M}} \# 3$ & \multirow{3}{*}{ Summer strategies } & - & $\mathrm{O}$ & - & - \\
\hline & $\mathrm{EM}_{\mathrm{M}} \# 4$ & & - & $\mathrm{O}$ & $\mathrm{O}$ & - \\
\hline & $\mathrm{EM}_{\mathrm{M}} \# 5$ & & - & $\mathrm{O}$ & $\mathrm{O}$ & $\mathrm{O}$ \\
\hline \multirow{5}{*}{ Shaft box type DSF } & $\mathrm{EM}_{\mathrm{S}} \# 1$ & \multirow{2}{*}{ Winter strategies } & $\mathrm{O}$ & - & - & - \\
\hline & $\mathrm{EM}_{\mathrm{S}} \# 2$ & & $\mathrm{O}$ & - & - & $\mathrm{O}$ \\
\hline & $\mathrm{EM}_{\mathrm{S}} \# 3$ & \multirow{3}{*}{ Summer strategies } & - & $\mathrm{O}$ & - & - \\
\hline & $\mathrm{EM}_{\mathrm{S}} \# 4$ & & - & $\mathrm{O}$ & $\mathrm{O}$ & - \\
\hline & $\mathrm{EM}_{\mathrm{S}} \# 5$ & & - & $\mathrm{O}$ & $\mathrm{O}$ & $\mathrm{O}$ \\
\hline
\end{tabular}

Note: BEM stands for the basic energy model, $\mathrm{EM}_{\mathrm{B}}$ stands for Box type DSF energy model, $\mathrm{EM}_{\mathrm{C}}$ stands for corridor type DSF energy model, $\mathrm{EM}_{\mathrm{M}}$ stands for multistory type DSF energy model, and $\mathrm{EM}_{\mathrm{S}}$ stands for shaft box type DSF energy model. 


\section{Analysis of Energy-Saving Effect by Season}

The energy analysis of DSF energy models, which implemented seasonal energy efficiency strategies, shows the effect of such strategies. As shown in Table 6, this study proposed the energy consumption of each energy model. For a detailed analysis on the effect of the introduction of the strategies, this study analyzed the first DSF type, the box type.

\subsection{Effect of Winter Strategies on Building Energy Consumption}

As shown in Table 6, winter energy efficiency strategies can be divided into two types: (i) static air buffer (Method_A1) as an airflow operating method; and (ii) GW (Method_B) as a method to improve thermal insulation.

\subsubsection{Effect of the Winter Strategy (Method_A1)}

In winter, the heating energy-saving effect of EMB \#1 with the static air buffer (Method_A1) was 3.20\% of the basic energy model, reflecting a decrease in the winter heating energy consumption (Table 6).

There was a substantial temperature gap between the cavity of $\mathrm{EM}_{\mathrm{B}} \# 1$ and outside the building (line in Figure 6). The temperature of the cavity continued to increase by the hour due to the heat gained by solar radiation within the duration of sunshine, showing a notable difference of up to $35.77{ }^{\circ} \mathrm{C}$ at 1:30 pm $\left(\mathrm{EM}_{\mathrm{B}} \# 1: 30.27{ }^{\circ} \mathrm{C}\right.$; outside: $\left.-4.5^{\circ} \mathrm{C}\right)$. Even when the heat generator is not operational, the temperature difference outside and inside the building was still over $15^{\circ} \mathrm{C}$. Thus, the heat inside the building was kept from being emitted outside, and $\mathrm{EM}_{\mathrm{B}} \# 1$ consumed lesser heating energy than the basic energy model (bar graphs in Figure 6). In winter, the airflow operating method in $\mathrm{EM}_{\mathrm{B}} \# 1$ was found to maintain the temperature inside the building and inside the cavity to a maximum.

Figure 6. Temperature-time profile and heating energy consumption on a winter day (basic energy model vs. $\left.\mathrm{EM}_{\mathrm{B}} \# 1\right)$.

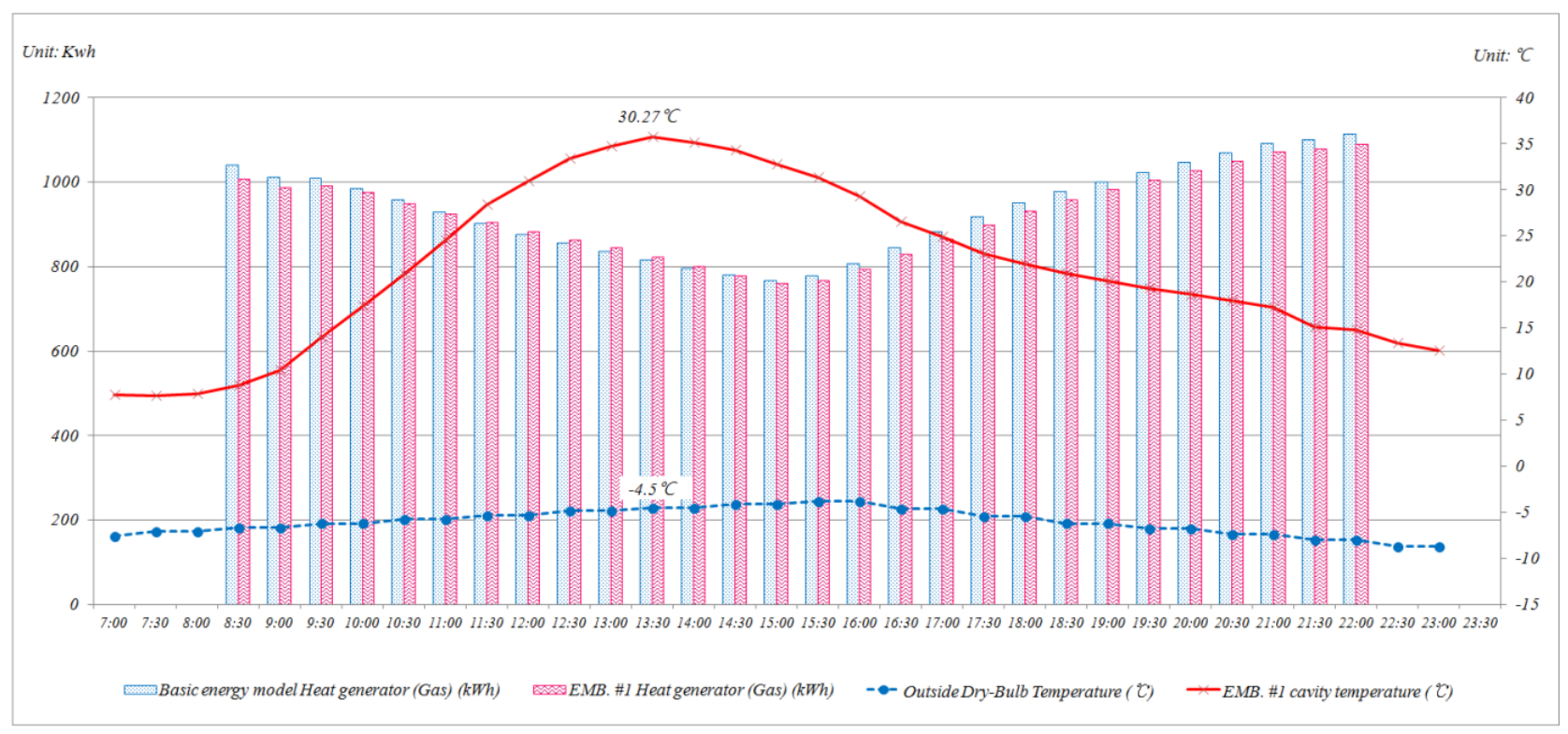


Table 6. Gas consumption by energy models with seasonal energy efficiency strategies.

\begin{tabular}{|c|c|c|c|c|c|c|c|}
\hline \multirow{3}{*}{ Classification } & \multirow{3}{*}{ Energy model } & \multirow{3}{*}{\multicolumn{2}{|c|}{$\begin{array}{c}\text { Seasonal energy efficiency } \\
\text { strategies }\end{array}$}} & \multicolumn{4}{|c|}{ Energy consumption } \\
\hline & & & & \multicolumn{2}{|c|}{ Winter } & \multicolumn{2}{|c|}{ Summer } \\
\hline & & & & Consumption (kWh) & Saving rate $(\%)$ & Consumption (kWh) & Saving rate $(\%)$ \\
\hline Existing facility & BEM & & - & 671,142 & - & 993,745 & - \\
\hline \multirow{5}{*}{ Box type DSF } & $\mathrm{EM}_{\mathrm{B}} \# 1$ & \multirow{2}{*}{ Winter } & (Method_A1) & 649,678 & 3.20 & - & - \\
\hline & $\mathrm{EM}_{\mathrm{B}} \# 2$ & & (Method_A1 + B) & 648,541 & 3.37 & - & - \\
\hline & $\mathrm{EM}_{\mathrm{B}} \# 3$ & \multirow{3}{*}{ Summer } & (Method_A2) & - & - & $1,008,888$ & -1.52 \\
\hline & $\mathrm{EM}_{\mathrm{B}} \# 4$ & & (Method_A2 + A3) & - & - & 881,119 & 11.33 \\
\hline & $\mathrm{EM}_{\mathrm{B}} \# 5$ & & (Method_A2 + A3 + B) & - & - & 880,261 & 11.42 \\
\hline \multirow{5}{*}{ Corridor type DSF } & $\mathrm{EM}_{\mathrm{C}} \# 1$ & \multirow{2}{*}{ Winter } & (Method_A1) & 657,496 & 2.03 & - & - \\
\hline & $\mathrm{EM}_{\mathrm{C}} \# 2$ & & (Method_A1 + B) & 654,383 & 2.50 & - & - \\
\hline & $\mathrm{EM}_{\mathrm{C}} \# 3$ & \multirow{3}{*}{ Summer } & (Method_A2) & - & - & $1,006,296$ & -1.26 \\
\hline & $\mathrm{EM}_{\mathrm{C}} \# 4$ & & (Method_A2 + A3) & - & - & 869,348 & 12.52 \\
\hline & $\mathrm{EM}_{\mathrm{C}} \# 5$ & & (Method_A2 + A3 + B) & - & - & 868,851 & 12.57 \\
\hline \multirow{5}{*}{ Multistory type DSF } & $\mathrm{EM}_{\mathrm{M}} \# 1$ & \multirow{2}{*}{ Winter } & (Method_A1) & 655,313 & 2.36 & - & - \\
\hline & $\mathrm{EM}_{\mathrm{M}} \# 2$ & & (Method_A1 + B) & 652,217 & 2.82 & - & - \\
\hline & $\mathrm{EM}_{\mathrm{M}} \# 3$ & \multirow{3}{*}{ Summer } & (Method_A2) & - & - & $1,003,995$ & -1.03 \\
\hline & $\mathrm{EM}_{\mathrm{M}} \# 4$ & & $($ Method_A2 + A3) & - & - & 868,302 & 12.62 \\
\hline & $\mathrm{EM}_{\mathrm{M}} \# 5$ & & $($ Method_A2 + A $3+B)$ & - & - & 867,844 & 12.67 \\
\hline \multirow{5}{*}{ Shaft box type DSF } & $E M_{S} \# 1$ & \multirow{2}{*}{ Winter } & (Method_A1) & 644,507 & 3.97 & - & - \\
\hline & $\mathrm{EM}_{\mathrm{S}} \# 2$ & & (Method_A1 + B) & 643,399 & 4.13 & - & - \\
\hline & $\mathrm{EM}_{\mathrm{S}} \# 3$ & \multirow{3}{*}{ Summer } & (Method_A2) & - & - & $1,020,428$ & -2.69 \\
\hline & $\mathrm{EM}_{\mathrm{S}} \# 4$ & & (Method_A2 + A3) & - & - & 903,837 & 9.05 \\
\hline & $\mathrm{EM}_{\mathrm{S}} \# 5$ & & $($ Method_A2 + A3 + B) & - & - & 870,575 & 12.39 \\
\hline
\end{tabular}

Note: BEM stands for the basic energy model, $\mathrm{EM}_{\mathrm{B}}$ stands for Box type DSF energy mode; $\mathrm{EM}_{\mathrm{C}}$ stands for corridor type DSF energy model; $\mathrm{EM}_{\mathrm{M}}$ stands for multistory type DSF energy model; $\mathrm{EM}_{\mathrm{S}}$ stands for the shaft box type DSF energy model; Method_A1 stands for static air buffer; Method_B stands for green wall; Method_A2 stands for external air curtain; Method A3 stands for natural ventilation. 


\subsubsection{Effect of Winter Strategies [(Method_A1) and (Method_B)]}

In winter, the heating energy saving effect of $\mathrm{EM}_{\mathrm{B}} \# 2$, which used the static air buffer (Method_A1) and green wall (Method_B), was 3.37\% larger than $\mathrm{EM}_{\mathrm{B}} \# 1$ (3.20\%), which used only the static air buffer (Method_A1) (Table 6). For a more detailed analysis, this study focused on the data on December 5, when the temperature was one of the lowest recorded for the year. Compared to the temperature inside the cavity, $\mathrm{EM}_{\mathrm{B}} \# 2$ was lower than $\mathrm{EM}_{\mathrm{B}} \# 1$, meaning that the amount of heat emitted from inside the building to the cavity was small (lines in Figure 7). GW blocked the heat transfer by improving the thermal insulation of the wall. As a result, $\mathrm{EM}_{\mathrm{B}} \# 2(648,541 \mathrm{kWh})$ had lesser heating energy consumption than $\mathrm{EM}_{\mathrm{B}} \# 1(649,678 \mathrm{kWh})$ (Table 6). In conclusion, the thermal bridge effect due to the improvement in thermal insulation was reduced by applying GW to the inner skin wall of DSF, resulting in heating energy savings effect in winter.

Based on the result above, two strategies were found effective in saving heating energy consumption: (i) preserving heat in the cavity through the static air buffer in winter (Method_A1) $\left(\mathrm{EM}_{\mathrm{B}} \# 1\right.$ compared with the basic energy model); and (ii) reducing the heat emitted from inside the building by reducing the thermal bridge effect with GW in winter (Method_B) $\left(\mathrm{EM}_{\mathrm{B}} \# 2\right.$ compared with $\left.\mathrm{EM}_{\mathrm{B}} \# 1\right)$.

Figure 7. Temperature-time profile and heating energy consumption on a winter's day $\left(\mathrm{EM}_{\mathrm{B}} \# 2\right.$ vs. $\left.\mathrm{EM}_{\mathrm{B}} \# 1\right)$.

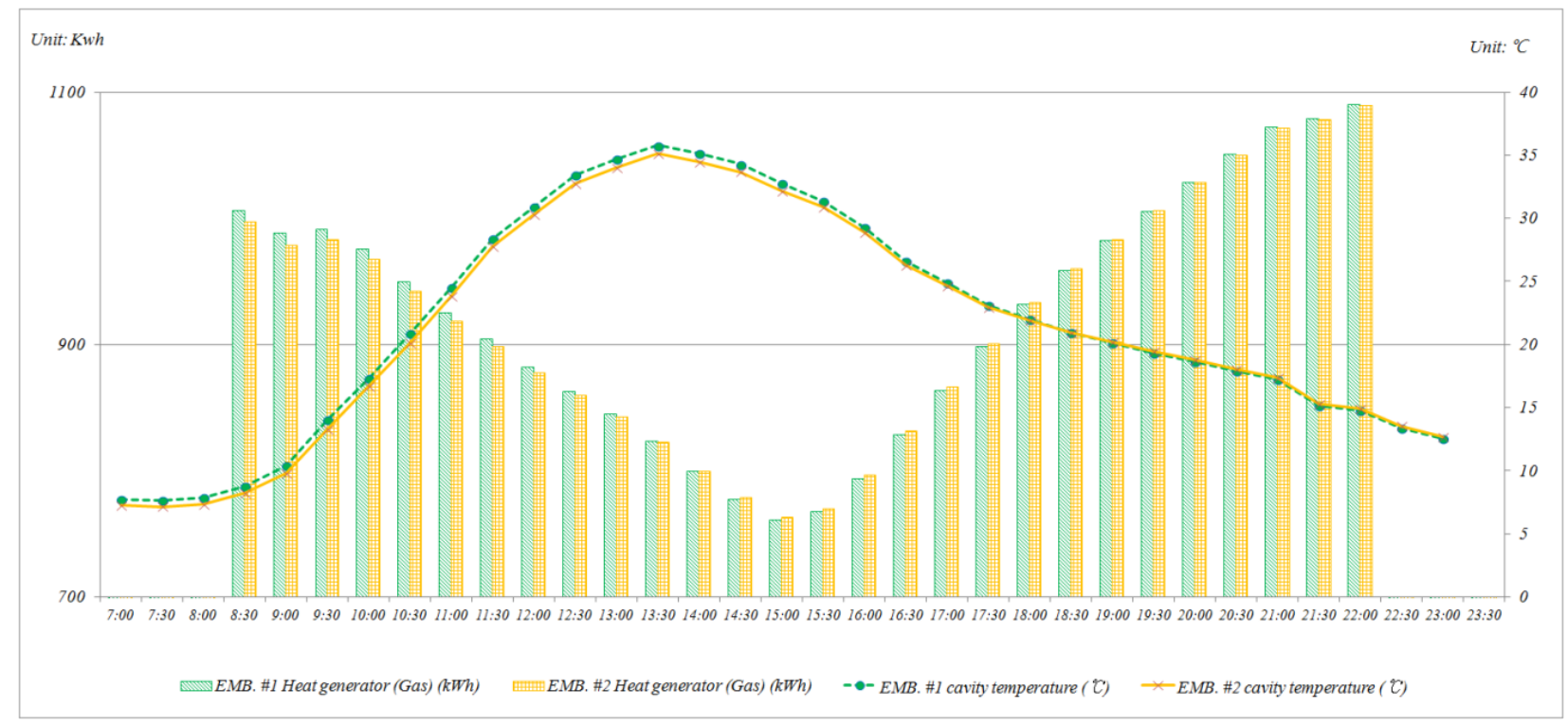

\subsection{Effect of Summer Strategies on Building Energy Consumption}

\subsubsection{Effect of Summer Strategy (Method_A2)}

As shown in Table 6, summer energy efficiency strategies can be divided into three parts: (i) external air curtain (Method_A2) as an airflow operating method; (ii) natural ventilation (Method_A3) as an airflow operating method; and (iii) GW (Method_B) as a method to improve thermal insulation.

In summer, the cooling energy saving effect of $\mathrm{EM}_{\mathrm{B}} \# 3$, which used the external air curtain (Method_A2) as an airflow operating method, was $-1.52 \%$ (Table 6). Namely, the summer cooling energy consumption increased. For a more detailed analysis, this study focused on the data on 3 August, 
when the temperature was one of the highest for the year. There was a significant temperature gap between the cavity of $\mathrm{EM}_{\mathrm{B}} \# 3$ and outside the building (lines in Figure 8). The temperature of the cavity did not go over $32.02{ }^{\circ} \mathrm{C}$ (at 15:00) during the duration of sunshine due to the external air curtain (Method_A2). However, after the duration of sunshine (from 20:00 to 9:30), the chiller was turned off, so the temperature inside the building rose. At this time, the maximum temperature difference between the cavity and inside the building was $7.56{ }^{\circ} \mathrm{C}$ at $21: 30\left(\mathrm{EM}_{\mathrm{B}} \# 3\right.$ : $32.36{ }^{\circ} \mathrm{C}$; outside: $24.80^{\circ} \mathrm{C}$ ), which was maintained almost throughout. Heat was not emitted outside the building, and to reduce the temperature inside the building, higher cooling energy consumption would be required than that of the basic energy model (bar graphs in Figure 8). Therefore, additional methods are required for the external air curtain (Method_A2) of $\mathrm{EM}_{\mathrm{B}} \# 3$ during summer to reduce the temperature inside the building and in the cavity after the duration of sunshine.

Figure 8. Temperature-time profile and cooling energy consumption on a summer day (basic energy model vs. $\mathrm{EM}_{\mathrm{B}} \# 3$ ).

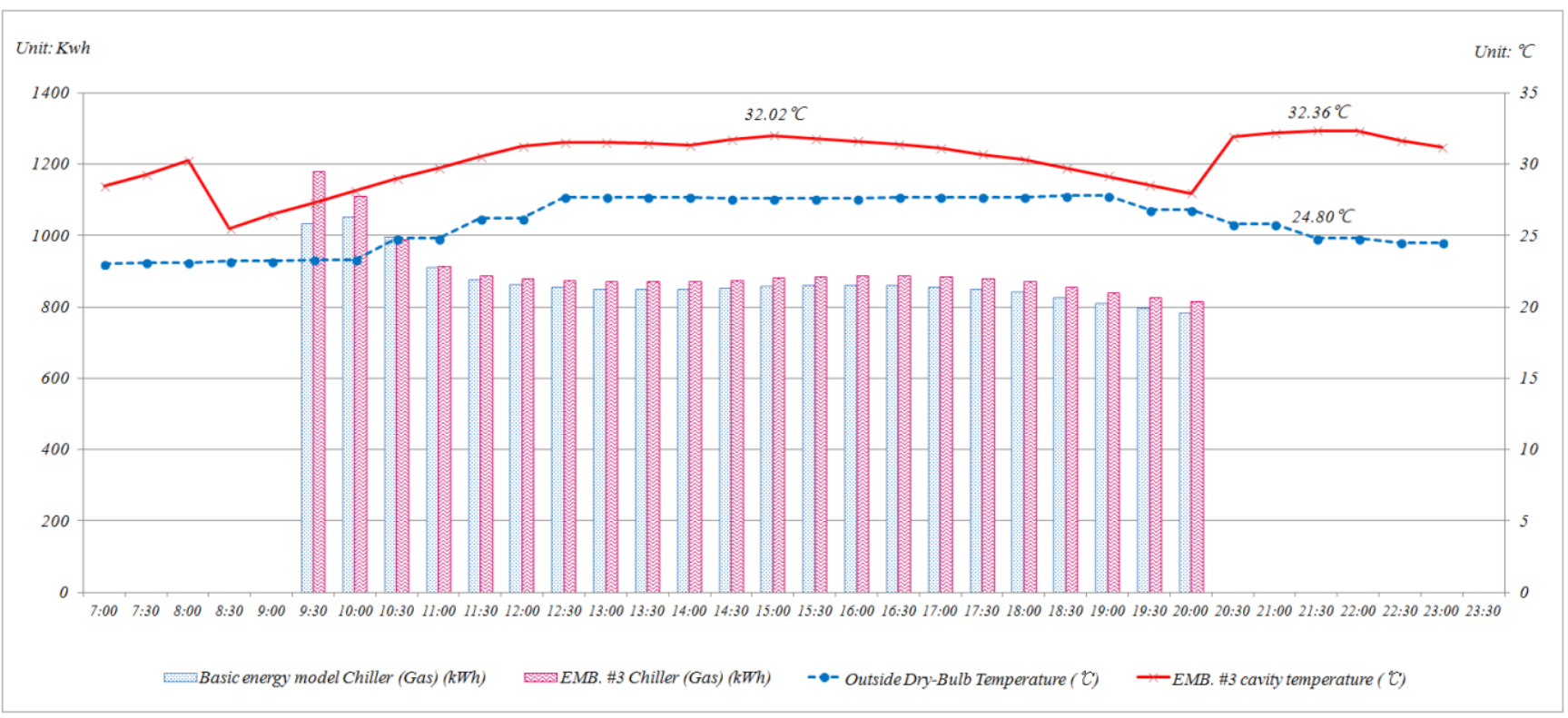

\subsubsection{Effect of Summer Strategies [(Method_A2) and (Method_A3)]}

As shown in Table 6, the cooling energy saving effect of $\mathrm{EM}_{\mathrm{B}} \# 4$, which added natural ventilation (Method_A3) to $\mathrm{EM}_{\mathrm{B}} \# 3$, was $11.33 \%$. Compared to $\mathrm{EM}_{\mathrm{B}} \# 3$ (-1.52\%), where cooling energy consumption increased in summer, $\mathrm{EM}_{\mathrm{B}} \# 4$ shows considerable amount of energy saving. For a more detailed analysis, this study focused on the data on 3 August, when the temperature was one of the highest for the year.

Furthermore, there was a significant temperature gap between the cavity of $\mathrm{EM}_{\mathrm{B}} \# 4$ and $\mathrm{EM}_{\mathrm{B}} \# 3$ from 20:00 to 9:30 (dotted lines in Figure 9). First, during the duration of sunshine prior to the operation of the chiller, the cavity temperature of $\mathrm{EM}_{\mathrm{B}} \# 4$ was lower than that of $\mathrm{EM}_{\mathrm{B}} \# 3$ by up to $6.59^{\circ} \mathrm{C}$ at 8:00 $\left(\mathrm{EM}_{\mathrm{B}} \# 4: 23.65^{\circ} \mathrm{C} ; \mathrm{EM}_{\mathrm{B}} \# 3: 30.24{ }^{\circ} \mathrm{C}\right)$. Also, the temperature inside the building in $\mathrm{EM}_{\mathrm{B}} \# 4$ was lower by up to $8.45^{\circ} \mathrm{C}$ compared to that of $\mathrm{EM}_{\mathrm{B}} \# 3\left(\mathrm{EM}_{\mathrm{B}} \# 4: 26.07{ }^{\circ} \mathrm{C} ; \mathrm{EM}_{\mathrm{B}} \# 3: 34.52{ }^{\circ} \mathrm{C}\right)$ (solid lines in Figure 9). Namely, $\mathrm{EM}_{\mathrm{B}} \# 4$, which added natural ventilation (Method_A3) when the chiller was not operational, prevented the rise in temperature due to solar radiation. Second, after the 
chiller ceased operating (from 21:00), natural ventilation (Method_A3) continued to reduce the temperature inside the building and in the cavity. Due to the lowered temperature inside the building, $\mathrm{EM}_{\mathrm{B}} \# 4$ consumed lesser cooling energy than $\mathrm{EM}_{\mathrm{B}} \# 3$ (bar graphs in Figure 9). In conclusion, the cooling energy saving effect was achieved by establishing summer airflow operating methods, including natural ventilation (Method_A3).

Figure 9. Temperature-time profile and cooling energy consumption on a summer day $\left(\mathrm{EM}_{\mathrm{B}} \# 4\right.$ vs. $\left.\mathrm{EM}_{\mathrm{B}} \# 3\right)$.

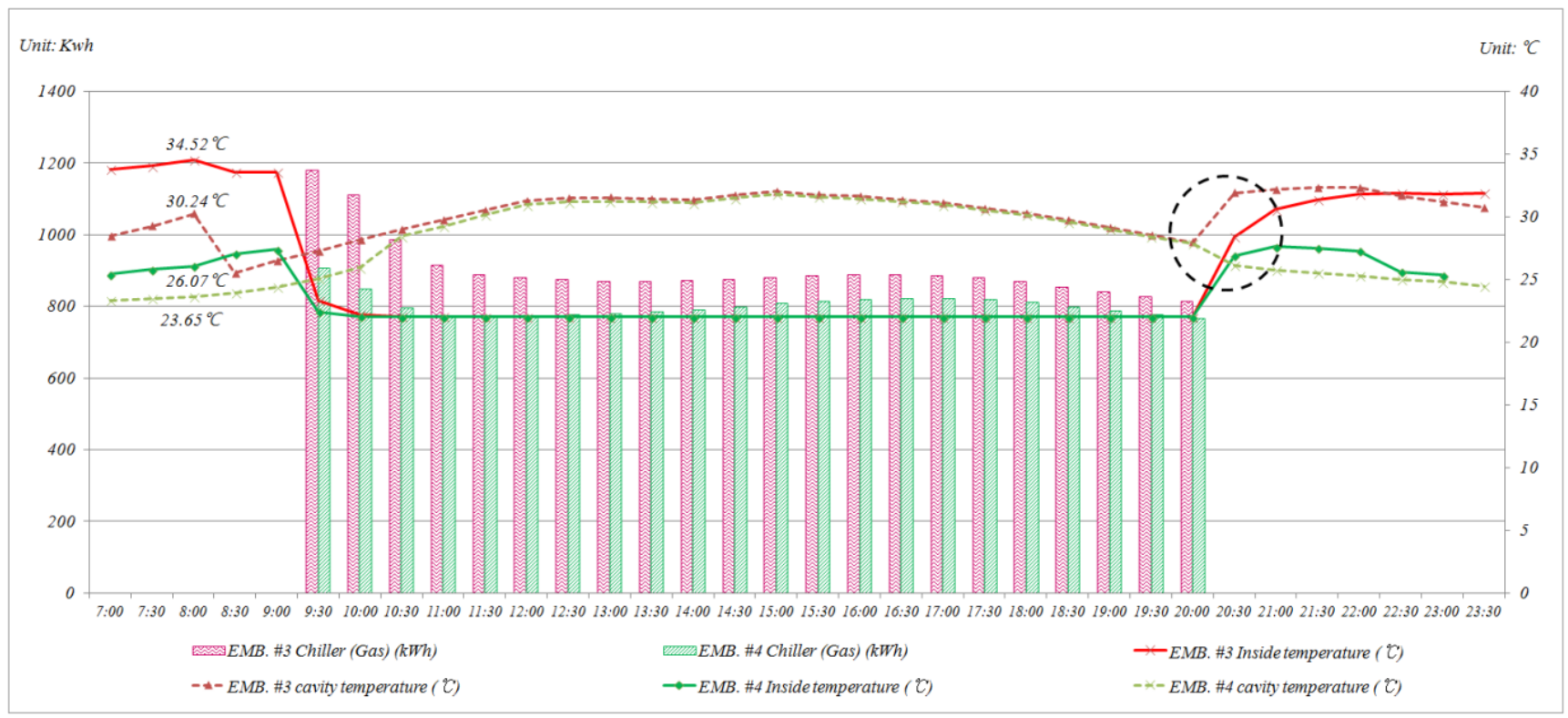

\subsubsection{Effect of Summer Strategies [(Method_A2), (Method_A3) and (Method_B)]}

Another strategy in reducing the inflow of heated air in the cavity to inside the building is by cutting down the thermal bridge effect by increasing the thermal insulation of the inner skin. The heat from the cavity to inside the building in summer can be reduced by using GW. In summer, the cooling energy saving effect of $\mathrm{EM}_{\mathrm{B}} \# 5$ was $11.42 \%$, which was more than that of $\mathrm{EM}_{\mathrm{B}} \# 4(11.32 \%)$ (Table 6). For a more detailed analysis, this study focused on the data on 3 August, when one of the highest temperatures for the year was recorded. The cavity temperature of $\mathrm{EM}_{\mathrm{B}} \# 5$ was higher than that of $\mathrm{EM}_{\mathrm{B}} \# 4$, meaning the inflow of heated air from the cavity to inside the building was smaller (Figure 10). Namely, GW reduced the thermal bridge effect and prevented heat transfer. As a result, the cooling energy consumption in $\mathrm{EM}_{\mathrm{B}} \# 5$ (880,261 kWh) was reduced, compared to $\mathrm{EM}_{\mathrm{B}} \# 4$ (881,119 kWh).

A similar tendency in energy savings attributed to the implementation of seasonal energy efficiency strategies was observed in corridor DSF, multistory DSF, and shaft box DSF (refer to Table 6). $\mathrm{EM}_{\mathrm{C}} \# 1$ (2.03\%), $\mathrm{EM}_{\mathrm{M}} \# 1$ (2.36\%), and $\mathrm{EM}_{\mathrm{S}} \# 1$ (3.97\%), which used the static air buffer (Method_A1), showed higher heating energy savings compared to the existing facility. Additionally, $\mathrm{EM}_{\mathrm{C}} \# 2$ (2.50\%), $\mathrm{EM}_{\mathrm{M}} \# 2$ (2.82\%), and $\mathrm{EM}_{\mathrm{S}} \# 2$ (4.13\%), which used GW (Method_B) to improve thermal insulation, showed higher heating energy savings than the $\mathrm{EM}_{\mathrm{C}} \# 1, \mathrm{EM}_{\mathrm{M}} \# 1$, and $\mathrm{EM}_{\mathrm{S}} \# 1$.

$\mathrm{EM}_{\mathrm{C}} \# 4$ (12.52\%), $\mathrm{EM}_{\mathrm{M}} \# 4$ (12.62\%), and $\mathrm{EM}_{\mathrm{S}} \# 4$ (9.05\%), which used both external air curtain (Method_A2) and natural ventilation (Method_A3), showed higher cooling energy savings than the existing facility. Furthermore, $\mathrm{EM}_{\mathrm{C}} \# 5$ (12.57\%), $\mathrm{EM}_{\mathrm{M}} \# 5$ (12.67\%), and $\mathrm{EM}_{\mathrm{S}} \#$ 5 (12.39\%), which 
used GW (Method_B) to improve thermal insulation, showed larger cooling energy savings than the $\mathrm{EM}_{\mathrm{C}} \# 4, \mathrm{EM}_{\mathrm{M}} \# 4$, and $\mathrm{EM}_{\mathrm{S}} \# 4$. Based on the results above, the seasonal energy efficiency strategies for saving heating and cooling energy consumption were effective.

Figure 10. Temperature-time profile and cooling energy consumption on a summer day (EMB \#4 vs. EMB \#5).

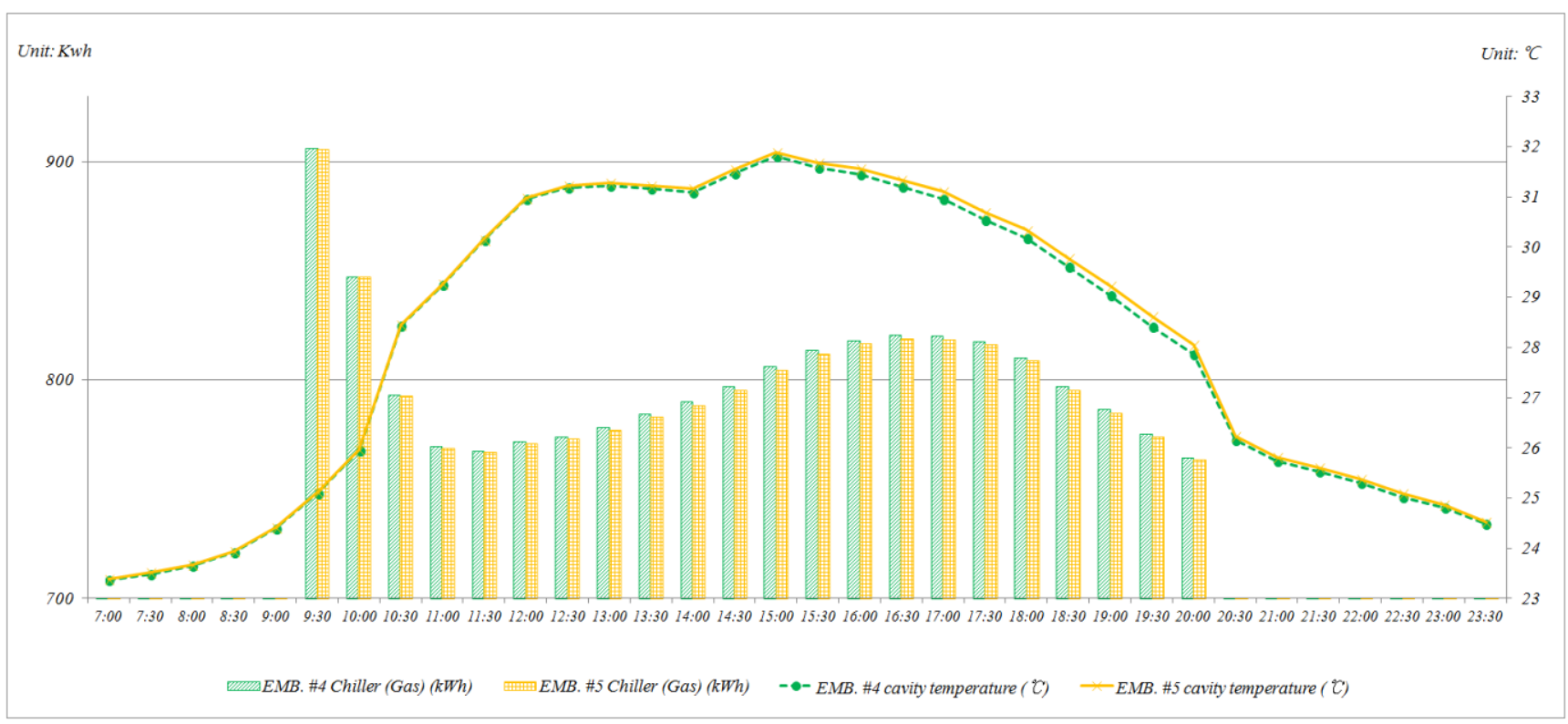

\section{LCC and $\mathrm{LCCO}_{2}$ Analyses for Selecting an Optimal DSF}

\subsection{System Boundary Conditions for $\mathrm{LCC}$ and $\mathrm{LCCO}_{2}$ Analyses}

By analyzing the energy-saving effects of the aforementioned energy models, an optimal DSF type in terms of energy savings can be selected. However, considering the constraints of the limited budget, a DSF type with the highest return on investment should be chosen. Therefore, this study conducted an economic and environmental assessment from the life cycle perspective. It considered reducing $\mathrm{CO}_{2}$ emission by saving energy consumption for the environmental assessment [Equation (2)]. The quantity of $\mathrm{CO}_{2}$ emission from heating and cooling energy consumption was converted into an economic value based on the profit from the sale of carbon credits, which is referred to as "Korea Certified Emission Reduction (KCERs)," (\$10.46/tCO $\mathrm{CO}_{2}$ equiv.) [64,65].

The amount of $\mathrm{CO}_{2}$ emission from gas energy consumption $\left(\mathrm{tCO}_{2}\right)=$

(The yearly amount of gas energy consumption $\left.\left(m^{3}\right)\right) \times$

(The ratio of the carbon emission factor of gas energy $\left.\left(\frac{t C}{\mathrm{~m}^{3}}\right)\right) \times$

(The ratio of the molecular weight of $\mathrm{CO}_{2}$ to carbon $\left(\frac{t \mathrm{CO}_{2}}{t \mathrm{C}}\right)$ )

where the ratio of the carbon emission factor of gas energy is $0.0006083 \mathrm{tC} / \mathrm{m}^{3}$, and the ratio of the molecular weight of $\mathrm{CO}_{2}$ to carbon is $44 \mathrm{tCO}_{2} / 12 \mathrm{tC}$. 
LCC and $\mathrm{LCCO}_{2}$ analyses should consider six factors: (i) the analysis approach; (ii) a realistic discount rate; (iii) the inflation and increase rate; (iv) the analysis period; (v) the starting point of the analysis; and (vi) the significant cost of ownership [49,66]. Table 7 shows the six factors of LCC and $\mathrm{LCCO}_{2}$ analyses used in this study.

Table 7. Key elements of the $\mathrm{LCC}$ and $\mathrm{LCCO}_{2}$ analyses.

\begin{tabular}{|c|c|c|}
\hline \multicolumn{2}{|c|}{ Classification } & Detailed description \\
\hline \multicolumn{2}{|c|}{ Analysis approach } & Present worth method $\left(\mathrm{SIR}_{40}\right)$ \\
\hline \multirow{3}{*}{ Real discount rate } & Interest & $3.30 \%$ \\
\hline & Gas & $0.11 \%$ \\
\hline & KCERs & $2.66 \%$ \\
\hline \multicolumn{2}{|c|}{ Analysis period } & 40 years \\
\hline \multicolumn{2}{|c|}{ Starting point of analysis } & 2012 \\
\hline \multirow{5}{*}{ Significant cost of ownership } & Initial construction cost & Initial investment cost \\
\hline & \multirow{2}{*}{ Operation \& maintenance cost } & Replacement/repair cost \\
\hline & & Energy consumption cost \\
\hline & \multirow{2}{*}{ Operation \& maintenance benefit } & Gas savings \\
\hline & & Benefit from KCERs \\
\hline
\end{tabular}

In implementing DSF, a higher savings to investment ratio (SIR) should be selected due to the limited budget. In life cycle perspectives, SIR refers to the ratio of the savings with additional benefit to investment cost that is converted to the present worth [Equation (3)], which is the index for relative evaluation. If SIR $\geq 1$, the project is feasible, and its breakeven point (BEP) is achieved. The real interest rate was calculated by the nominal interest rate and the inflation rate [Equation (4)] [67-69].

$$
S I R=\frac{\sum_{t=0}^{n} \frac{S_{t}+B_{t}}{(1+r)^{t}}}{\sum_{t=0}^{n} \frac{I_{t}}{(1+r)^{t}}}
$$

where SIR is savings to investment ratio; $S_{t}$ is gas energy savings in year $t ; B_{t}$ is benefit from KCERs in year $t$; $I_{t}$ is investment in year $t$; $r$ is the real discount rate; and $n$ is the period of the life cycle analysis:

$$
i=\frac{\left(1+i_{n}\right)}{(1+f)}-1
$$

where $i$ is the real discount rate; $i_{n}$ is the nominal interest rate; and $f$ is the inflation rate, the gas price growth rate, and the carbon dioxide emission trading price growth rate. The service life of a steel reinforced concrete building was set to 40 years, which was provided by "the Standard Service Life and Service Life Scope Chart in the Enforcement Regulations on Corporate Income Tax Act" [49].

\subsection{Optimal DSF in Terms of SIR and BEP}

Table 8 shows the results of the LCC and $\mathrm{LCCO}_{2}$ analyses of four DSFs with seasonal energy efficiency strategies. This study analyzed $\mathrm{SIR}_{40}$ and BEP from life-cycle perspectives. The results of 
the $\mathrm{LCC}$ and $\mathrm{LCCO}_{2}$ analyses on each of the DSF are as follows: from the perspective of $\mathrm{SIR}_{40}$, the multistory, shaft box, corridor, and box types were analyzed in the order of No. 1 (3.20), No. 2 (3.11), No. 3 (3.05), and No. 4 (2.85), respectively. From the perspective of the BEP, the multistory, shaft box, and box types all took nine years, while the corridor type took 11 years. In summary, the multistory type was selected as an optimal DSF in terms of economic and environmental aspects, because while the investment cost (additional initial cost: $\$ 190,743$; additional replacement cost: $\$ 113,395$ ) was lesser than the others, it achieved higher savings with benefit (life cycle energy saving benefit: \$958,399; KCER income: \$15,748). The larger the unit of the cavity was, the higher the temperature difference between an opening became, resulting in better ventilation. Thus, more heat emitted from the cavity outside the building translates to higher cooling energy savings.

Table 8. $\mathrm{LCC}$ and $\mathrm{LCCO}_{2}$ analyses on four DSF with seasonal energy efficiency strategies.

\begin{tabular}{|c|c|c|c|c|c|c|c|c|}
\hline \multirow[t]{2}{*}{ Double Skin Façade } & \multirow{2}{*}{$\begin{array}{r}\begin{array}{c}\text { Additional } \\
\text { initial cost }\end{array} \\
(\$) \\
\end{array}$} & \multirow{2}{*}{$\begin{array}{c}\begin{array}{c}\text { Additional } \\
\text { replacement cost }\end{array} \\
(\$) \\
\end{array}$} & \multirow{2}{*}{$\begin{array}{c}\begin{array}{c}\text { LCES } \\
\text { benefit }\end{array} \\
(\$)\end{array}$} & \multirow{2}{*}{$\begin{array}{c}\text { KCER } \\
\text { income } \\
(\$) \\
\end{array}$} & \multicolumn{2}{|c|}{ SIR $_{40}$} & \multicolumn{2}{|c|}{ BEP } \\
\hline & & & & & Value & Rank & Year & Rank \\
\hline Box type & 200,414 & 120,958 & 900,559 & 14,798 & 2.85 & 4 & 9 & 1 \\
\hline Corridor & 195,599 & 117,192 & 937,402 & 15,403 & 3.05 & 3 & 11 & 4 \\
\hline Multistory & 190,743 & 113,395 & 958,399 & 15,748 & 3.20 & 1 & 9 & 1 \\
\hline Shaft box & 203,286 & 123,204 & 998,674 & 16,410 & 3.11 & 2 & 9 & 1 \\
\hline
\end{tabular}

Note: LCES stands for life cycle energy saving; KCER stands for Korea Certified Emission Reduction; SIR stands for saving to investment ratio; BEP stands for break-even point; and the exchange rate (KRW/USD) is 1,112.5 won to a U.S. dollar (as of May.14.2013).

\section{Conclusions}

To improve the effect of the DSF implementation, this study established seasonal energy efficiency strategies and analyzed the effect of these strategies through a case study. It aimed to select an optimal DSF in terms of SIR. The university facilities were statistically significant in terms of energy consumption. It was determined that the energy consumption of the university facilities in 2010 was 295 thousand TOE, which is ranked second among all types of buildings in South Korea (refer to Table A2). Especially, the library facility is the main factor of energy consumption and exists in all the university. Therefore, the university library facility could have a great effect on the whole energy consumption of South Korea.

The seasonal energy efficiency strategies were established in summer and in winter. First, to establish winter-energy-efficient strategies, a combination of two methods was considered: (i) static air buffer (Method_A1) as an airflow operating method; and (ii) GW (Method_B) for improving thermal insulation. Next, to establish summer-energy-efficient strategies, a combination of the following three methods was considered: (i) external air curtain (Method_A2) as an airflow operating method; (ii) natural ventilation (Method_A3) as an airflow operating method; and (iii) GW (Method_B) for improving thermal insulation (refer to Table 3).

The energy consumption analysis on the energy models showed that the seasonal energy efficiency strategies were effective during both summer and winter seasons. First, in terms of winter-energy-efficiency strategies, the implementation of the static air buffer (Method_A1) as an 
airflow operating method to $\mathrm{EM}_{\mathrm{S}} \# 1$ (shaft box DSF) resulted in $644,507 \mathrm{kWh}$, with a reduction rate of up to $3.97 \%$ in heating energy consumption. Also, to reduce the thermal bridge effect, the use of GW as a method for improving thermal insulation showed that $\mathrm{EM}_{\mathrm{S}} \# 3$ (shaft box DSF and GW) was $643,399 \mathrm{kWh}$ with a reduction ratio of up to $4.13 \%$ in heating energy consumption.

Next, in terms of summer-energy-efficiency strategies, the implementation of the airflow operating methods including natural ventilation showed that the cooling energy consumption of $\mathrm{EM}_{\mathrm{S}} \# 4$ (multistory DSF) was $868,302 \mathrm{kWh}$, with a reduction rate of up to $12.62 \%$. Also, to reduce the thermal bridge effect, the use of GW as a method for improving thermal insulation showed that the cooling energy consumption of $\mathrm{EM}_{\mathrm{S}} \# 5$ (multistory DSF and GW) was $867,844 \mathrm{kWh}$ with a reduction rate of up to $12.67 \%$.

Finally, to maximize $\mathrm{SIR}_{40}$ and minimize $\mathrm{BEP}_{40}$ through the $\mathrm{LCC}$ and $\mathrm{LCCO}_{2}$ analyses, this study selected an optimal DSF with seasonal energy efficiency strategies, which was the multistory DSF with $\mathrm{SIR}_{40}$ (3.20) and $\mathrm{BEP}_{40}$ (nine years). The analysis showed that this optimal DSF resulted in smaller investment cost (additional initial cost: $\$ 190,743$; additional replacement cost: $\$ 113,395$ ) and higher savings with benefits (LCES benefit: \$958,399; KCER income: \$15,748).

The results of this study can be used in making decisions regarding: (i) seasonal energy efficiency strategies to save heating and cooling energy consumption in the East Asian monsoon climate region with a high temperature gap in summer and in winter; and (ii) application not only to existing buildings but also for new buildings.

The research team plans to conduct the following future research: (i) an optimal design according to the types of DSFs in terms of energy performance based on cavity depth, the size of an opening, and the position of the shading device of a DSF; (ii) airflow operating methods by season as well as optimal airflow operating methods that change in real-time, depending on the change in temperature inside and outside the building; (iii) thermal bridge effect reduction through thermal insulation of the applied GW, as well as the effects of sunblock and air purification of the applied GW; and (iv) decision support system for the sustainable design and management of buildings based on the long term validation with consideration of the deterioration process.

\section{Acknowledgments}

This work was supported by the National Research Foundation of Korea (NRF) grant funded by the Korea government (MSIP; Ministry of Science, ICT \& Future Planning) (No. 2012-004376 \& No. 2012-0001247).

\section{Conflicts of Interest}

The authors declare no conflict of interest. 


\section{Appendix}

Table A1. Space configuration and operating hours of target library ("Y" university library).

\begin{tabular}{ccc}
\hline Space configuration & Floor & Operating hours \\
\hline Reading rooms & $2-5$ Floor & AM 6-PM 11 \\
\multirow{2}{*}{ Study rooms } & 1 Floor & Open 24 hours \\
\cline { 2 - 3 } & 6 Floor & Open 24 hours \\
\cline { 2 - 3 } PC Seats & B1 Floor & Open 24 hours \\
\cline { 2 - 3 } & 6 Floor & Open 24 hours \\
\hline
\end{tabular}

Table A2. Energy consumption by the types of buildings in South Korea.

\begin{tabular}{cccccccccc}
\hline Year & \multicolumn{2}{c}{$\mathbf{2 0 0 8}$} & \multicolumn{2}{c}{$\mathbf{2 0 0 9}$} & \multicolumn{3}{c}{$\mathbf{2 0 1 0}$} \\
\hline Category & $\begin{array}{c}\text { TOE } \\
\text { (thousand) }\end{array}$ & Rate & Rank & $\begin{array}{c}\text { TOE } \\
\text { (thousand) }\end{array}$ & Rate & Rank & $\begin{array}{c}\text { TOE } \\
\text { (thousand) }\end{array}$ & Rate & Rank \\
\hline Residential building & 487 & $23.70 \%$ & 1 & 453 & $22.20 \%$ & 1 & 462 & $21.30 \%$ & 1 \\
University & 263 & $12.80 \%$ & 3 & 269 & $13.20 \%$ & 2 & 295 & $13.60 \%$ & 2 \\
Department store & 267 & $13.00 \%$ & 2 & 260 & $12.80 \%$ & 3 & 292 & $13.50 \%$ & 3 \\
Hospital & 230 & $11.20 \%$ & 4 & 239 & $11.70 \%$ & 4 & 254 & $11.70 \%$ & 4 \\
Hotel & 210 & $10.20 \%$ & 5 & 213 & $10.50 \%$ & 5 & 234 & $10.80 \%$ & 5 \\
Research Lab & 88 & $4.30 \%$ & 6 & 94 & $4.60 \%$ & 6 & 111 & $5.10 \%$ & 6 \\
Public building & 69 & $3.40 \%$ & 7 & 72 & $3.50 \%$ & 7 & 106 & $4.90 \%$ & 7 \\
Telephone company & 44 & $2.10 \%$ & 8 & 39 & $1.90 \%$ & 8 & 46 & $2.10 \%$ & 8 \\
Non classified & 401 & $19.50 \%$ & - & 398 & $19.50 \%$ & - & 370 & $17.10 \%$ & - \\
Total & 2059 & $100 \%$ & - & 2037 & $100 \%$ & - & 2170 & $100 \%$ & - \\
\hline
\end{tabular}

\section{References}

1. Heffernan, V. Roofs and the environment; Can. Consult. Eng. 2003, 44, 35-39.

2. Chicago Climate Exchange. $\mathrm{CO}_{2}$ Market Data 2011. Available online: http://www.chicagoclimatex.com/ market/data/summary.jsf (accessed on 30 May 2013).

3. Chan, A.L.S.; Chow, T.T.; Fong, K.F.; Lin, Z. Investigation on energy performance of double skin façade in Hong Kong. Energy Build. 2009, 41, 1135-1142.

4. Wang, P.C. Natural Ventilation in Double-Skin Façade Design for Office Buildings in Hot and Humid Climate. Ph.D. Thesis, University of New South Wales, Kensington, Australia, December 2008.

5. Bouden, C. Influence of glass curtain walls on the building thermal energy consumption under Tunisian climatic conditions: The case of administrative buildings. Renew. Energy 2007, 32, 141-156.

6. Shameri, M.A.; Alghoul, M.A.; Sopian, K.; Zain, M.F.M.; Elayeb, O. Perspectives of double skin façade systems in buildings and energy saving. Renew. Sustain. Energy Rev. 2011, 15, 1468-1475.

7. Gratia, E.; Herde, A.D. Are energy consumptions decreased with the addition of a double-skin? Energy Build. 2007, 39, 605-619.

8. Ballestini, G.; Carli, M.D.; Masiero, N.; Tombola, G. Possibilities and limitations of natural ventilation in restored industrial archaeology buildings with a double-skin facade in Mediterranean climates. Build. Environ. 2005, 40, 983-995. 
9. Su, S.; Chen, J. Analysis of heat conduction of anisotropic building materials. Adv. Mater. Res. 2011, 287, 1227-1232.

10. Stec, W.; Passen, D. Defining the Performance of the Double Skin Facade with the Use of the Simulation Model. In Proceedings of Building Simulation, the 8th International Building Performance Simulation Association (IBPSA) Conference, Eindhoven, The Netherlands, 11-14 August 2003.

11. Pekdemir, E.A.; Muehleisen, R.T. A Parametric Study of the Thermal Performance of Double Skin Facades at Different Climates Using Annual Energy Simulation. In Proceedings of 5th National Conference of International Building Performance Simulation Association IBPSA-USA, Madison, WI, USA, 1-3 August 2012.

12. Rawn, W. Case Study: A Double-Skin Glass Wall; Associates Architects Inc.: Boston, MA, USA, 2010.

13. Boake, T.M.; Harrison, K.; Chatham, A. The Tectonics of the Double Skin: North American Case Studies; University of Waterloo: Waterloo, Canada, 2001.

14. Xu, L.; Ojima, T. Field experiments on natural energy utilization in a residential house with a double skin façade system. Build. Environ. 2007, 42, 2014-2023.

15. Gracia, A.; Navarro, L.; Castell, A.; Pardo, A.R.; Alvarez, S. Experimental study of a ventilated façade with PCM during winter period. Energy Build. 2012, 58, 324-332.

16. Fukuyo, K. Heat flow visualization for thermal bridge problems. Int. J. Refrig. 2003, 26, 614-617.

17. Ding, W.; Hasemi, Y.; Yamada, T. Natural ventilation performance of a double-skin facade with a solar chimney. Energy Build. 2005, 37, 411-418.

18. Mingotti, N.; Chenvidyakarn, T.; Woods, A.W. The fluid mechanics of the natural ventilation of a narrow-cavity double-skin façade. Build. Environ. 2011, 46, 807-823.

19. Gratia, E.; Herde, A.D. Is day natural ventilation still possible in office buildings with a double-skin façade? Build. Environ. 2004, 39, 399-409.

20. Gratia, E.; Herde, A.D. Double-skin façade to apartment housing ventilation in an office building with a double-skin façade. Sol. Energy 2007, 81, 435-448.

21. American Society of Heating, Refrigerating and Air-Conditioning Engineers (ASHRAE). ASHRAE Guideline 14-2002; ASHRAE: Atlanta, GA, USA, 2002.

22. Yoshikane, T.; Kimura, F.; Emori, S. Numerical study on Baiu front genesis by heating constrast between land and ocean. J. Meteorol. Soc. Jpn. 2001, 79, 671-686.

23. Lee, H.W.; Kim, E.J.; Park, S.S.; Choi, J.H. Effects of climate change on the thermal structure of lakes in the Asian Monsoon Area. Clim. Change 2012, 112, 859-880.

24. Boo, K.O.; Martin, G.; Sellar, A.; Senior, C.; Byun, Y.H. Evaluating the East Asian monsoon simulation in climate models. J. Geophys. Res. Atmos. 2011, 116, doi: 10.1029/2010JD014737.

25. Webster, P.J.; Magana, V.O.; Palmer, T.N.; Shukla, J.; Tomas, R.A.; Yanai, M.; Yasunari, T. Monsoon: Processes, predictability, and the prospects for prediction. J. Geophys. Res. Oceans 1998, 103, 14451-14510.

26. Manz, H. Total solar energy transmittance of glass double façades with free convection. Energy Build. 2004, 36, 127-36.

27. Grande, I.P.; Meseguer, J.; Alonso, G. Influence of glass properties on the performance of double-glazed facades. Appl. Therm. Eng. 2005, 25, 3163-75. 
28. Zhang, X.; Liu, J.; Chen, Z.; Wang, X.; Wang, M.; Ning, L. Thermal bridges in building envelope in hot summer and cold winter areas of thinking. Appl. Mech. Mater. 2012, 117, 1211-1214.

29. Capozzoli, A.; Gorrino, A.; Corrado, V. A building thermal bridges sensitivity analysis. Appl. Energy 2013, 107, 229-243.

30. Feist, W.; Peper, S.; Gorg, M. CEPHEUS Project Information No.38: Final Public Report. Available online: http://www.passivehouse.com/ (accessed on 12 August 2013).

31. Evola, G.; Margani, G.; Marletta, L. Energy and cost evaluation of thermal bridge correction in Mediterranean climate. Energy Build. 2011, 43, 2385-2393.

32. Perez, G.; Rincon, L.; Vila, A.; Gonzalez, J.M.; Cabeza, L.F. Green vertical systems for buildings as passive systems for energy savings. Appl. Energy 2011, 88, 4854-4859.

33. Di, H.; Wang, D. Cooling effect of ivy on a wall. Exp. Heat Transf. 1999, 12, 235-45.

34. Akbari, H.; Kurn, D.M.; Bretz, S.E.; Hanford, J.W. Peak power and cooling energy savings of shade trees. Energy Build. 1997, 25, 139-48.

35. Eumorfopoulou, E.A.; Kontoleon, K.J. Experimental approach to the contribution of plant-covered walls to the thermal behaviour of building envelopes. Build. Environ. 2009, 44, 1024-1038.

36. Kontoleon, K.J.; Eumorfopoulou, E.A. The effect of the orientation and proportion of a plant-covered wall layer on the thermal performance of a building zone. Build. Environ. 2010, 45, 1287-1303.

37. Hoyano, A. Climatological uses of plants for solar control and the effects on the thermal environment of a building. Energy Build. 1988, 11, 181-199.

38. Baldinelli, G. Double skin facades for warm climate regions: Analysis of a solution with an integrated movable shading system. Build. Environ. 2009, 44, 1107-1118.

39. Kim, S.Y.; Song, K.D. Determining photosensor conditions of a daylight dimming control system using different double-skin envelope configurations. Indoor Built Environ. 2007, 46, 411-425.

40. Gratia, E.; Herde, A.D.; Natural cooling strategies efficiency in an office building with a double-skin façade. Energy Build. 2004, 36, 1139-1152.

41. Aleksandar, S.A.; Tanja, B.C.; Damir, D.D.; Ivan, H.S. Development of simple calculation model for energy performance of double skin facades. Therm. Sci. 2012, 16, S251-S267.

42. Szokolay, S.V. Introduction to Architectural Science: The Basis of Sustainable Design, 2nd ed.; Elsevier Science \& Technology Books: Burlington, MA, USA, 2008.

43. Poirazis, H. Double Skin Facades for Office Buildings; Report EBD-R-04/3 2004; Division of Energy and Building Design, Department of Construction and Architecture, Lund Institute of Technology: Lund, Sweden, 2004.

44. Oesterle, E.; Lieb R.D.; Lutz, M.; Heusler, W. Double-Skin Facades Integrated Planning; Prestel Verlag GmbH Co.KG: Munich, Germany, 2001.

45. Theodosiou, T.G. Summer period analysis of the performance of a planted roof as a passive cooling technique. Energy Build. 2003, 35, 909-917.

46. Frankenstein, S.; Koenig, G. Fast All-Season Soil Strength (FASST); US Army Corps of Engineers: Washington, DC, USA, 2004.

47. Wong, N.H.; Cheong, D.K.W.; Yan, H.; Ong, C.L.; Sia, A. The effects of rooftop garden on energy consumption of a commercial building in Singapore. Energy Build. 2004, 35, 353-364. 
48. Fang, C. Evaluating the thermal reduction effect of plant layers on rooftops. Energy Build. 2008, 40, 1048-1052.

49. Kim, J.; Hong, T.; Koo, C. Economic and environmental evaluation model for selecting the optimum design of green roof systems in elementary schools. Environ. Sci. Technol. 2012, 46, 8475-8483.

50. Scurlock, J.M.O.; Asner, G.P.; Gower, S.T. Global Leaf Area Index Data form Field Measurements, 1932-2000; Oak Ridge National Laboratory Distributed Active Archive Center: Oak Ridge, TN, USA, 2001.

51. Construction Association of Korea (CAK). General Information for Construction; Construction Association of Korea: Seoul, Korea, 2011.

52. Construction Association of Korea (CAK). Monthly Construction Market Price; Construction Association of Korea, Seoul, Korea, 2011.

53. Korea Energy Management Corporation (KEMCO). Energy Conservation Statistics. Available online: http://www.kemco.or.kr/ (accessed on 23 July 2013).

54. Korea University and College Library Association (KUCLA). Korea University and College Library Statistics. Available online: http://www.kucla.or.kr/ (accessed on 23 July 2013).

55. DesignBuilder EnergyPlus Simulation Documentation for DesignBuilder v3.0.; DesignBuilder Software Ltd.: Stroud, UK, 2011.

56. Crawley, D.B.; Lawrie, L.K.; Pedersen, C.O.; Winkelmann, F.C. EnergyPlus: Energy simulation program. ASHRAE. J. 2000, 42, 49-56.

57. Pappas, A.; Reilly, S. Energy Performance of a Double Skin Facade. In Proceedings of International Solar Energy Conference, Colorado, USA, 9-13 July, 2006; pp. 653-657.

58. Jiang, Q.; Long, W.D. Energy efficiency and design optimization of double-skin facade buildings. J. HV AC 2006, 36, 58-63.

59. Hashemi, N.; Fayaz, R.; Sarshar, M. Thermal behaviour of a ventilated double skin facade in hot arid climate. Energy Build. 2010, 42, 1823-1832.

60. EnergyPlus Input Output Reference. The Encyclopedic Reference to EnergyPlus Input and Output, 2010. Available online: http://www.energyplus.gov (accessed on 23 July, 2013).

61. Chen, Q.; van der Kooi, J. ACCURACY-a computer program for combined problems of energy analysis, indoor airflow, and air quality. ASHRAE Trans. 1988, 94, 196-214.

62. Zhai, Z.; Chen, Q.; Haves, P.; Klems, J.H. On approaches to couple energy simulation and computational fluid dynamics programs. Build. Environ. 2002, 37, 857-864.

63. Yu, Z.; Fung, B.; Haghighat, F.; Yoshino, H.; Morofsky, E. A systematic procedure to study the influence of occupant behavior on building energy consumption. Energy Build. 2011, 43, 1409-1417.

64. Korea Energy Management Corporation (KEMCO). Automatic Calculation of TOE and $\mathrm{CO}_{2}$ emissions, 2009. Available online: http://co2.kemco.or.kr/ (accessed on 23 May 2013)

65. Korea Energy Management Corporation (KEMCO). Energy and Climate Change Handbook 2010; KEMCO: Seoul, Korea, 2010.

66. Dell'Isola, A.J.; Kirk, S.J. Life Cycle Costing for Facilities; Reed Construction Data: Kingston, MA, USA, 2003.

67. Bank of Korea Economic Statistics System (ECOS). Available online: http://ecos.bok.or.kr/ (accessed on 30 May 2013). 
68. Korean Statistical Information Service (KOSIS). Available online: http://www.kosis.kr/ (accessed on 30 May 2013).

69. Korea Ministry of Knowledge Economy (KMKE). Prime Cost Calculation Standard of Energy Service Company (ESCO) Projects; KMKE: Seoul, Korea, 2009.

(C) 2013 by the authors; licensee MDPI, Basel, Switzerland. This article is an open access article distributed under the terms and conditions of the Creative Commons Attribution license (http://creativecommons.org/licenses/by/3.0/). 